\title{
Stromatactis cavities in sediments and the role of coarse-grained accessories
}

\author{
JINDŘICH HLADIL, MAREK RŮŽIČKA \& LEONA KOPTíKOVÁ
}

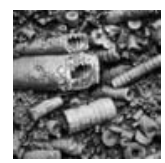

The analysis of previous experimental work made on the simulation of stromatactis-like cavities in rapidly settling suspensions of particulate matter substantiates the continuation of experiments toward identifying the conditions of cavity formation. It has been suggested that the most promising directions in this experimental work involve the simplification of complex factors (e.g., variables that derive from the properties of particles and media, as well as the sedimentation dynamics of slurries). Our new hydrodynamic concept of stromatactis formation addresses the traditional key arguments of previous authors on the origins of stromatactis systems. The direct production of stromatactis-type cavities during the sedimentation of fine particulate, polydisperse, multimodal aquatic suspended matter can be characterized in terms of competition between fluids escaping from compressed, diluted domains, and the dynamic effects of the dense packing of solid particles on their boundaries, the latter gradually overtaking from the former, until a middle layer of sediment is sufficiently stabilized and the first internal sedimentation from residual suspensions begins. With the earliest stabilization of the grain-supported, skeleton-like structures in the sediment, low domical but surprisingly stable vaults develop above the cavity zones. Underneath the coalescing arched structures, there often remain places in which grains can still be fluidized, and which consequently enable the further widening of these primary cavities. The specific grain size distribution is derived from natural counterparts, an attribute combined with the high internal friction angle, and increases the final sediment cohesion and stability. This process is particularly effective when highly polydisperse-multimodal sediment materials have highly angular, rugged, or potentially cohesive grains. When the relatively coarsest- and finest-grained fractions are present in increased amounts, the energy dissipation of the dense turbulent slurry is enhanced, and the stromatactis-producing mid-layer is gradually sealed by a relatively impermeable, non-stromatactis, very fine-grained cover in the upper part of the deposit. Two categories of experiments are discussed in this paper. The first is aimed at explaining how moderately large particles can interact with each other. In this category of experiments, moderately graded tridisperse mixtures of angular or highly textured particles tended to produce firmly packed clusters with ensuing domical vaulting above cavities. The second group of experiments is based on combinations of bidisperse mixtures of large grains with polydisperse nearly-unimodal matrices of small angular grains. These two components, if used separately, have close to zero capacity for producing any type of stromatactis-like cavities. However, once they were combined, even modest amounts of these large grains led to the growth of spacious cavity systems, particularly if artificial crinoid columnals were present. The comparison of our experimental results with natural examples suggest that crinoid columnals must be regarded as an important, although not indispensable accelerator of stromatactis cavity production. $\bullet$ Key words: sedimentation experiments, polydisperse suspensions, stromatactis cavities, crinoid columnals, carbonate sediments.

HLADIL, J., RŮŽIČKA, M. \& KOPTíKOVÁ, L. 2006. Stromatactis cavities in sediments and the role of coarse-grained accessories. Bulletin of Geosciences 81(2), 123-146 (7 figures). Czech Geological Survey, Prague. ISSN 1214-1119. Manuscript received January 31, 2006; accepted in revised form April 11, 2006; issued June 30, 2006.

Jindrich Hladil, Academy of Sciences of the Czech Republic, Institute of Geology, Rozvojová 269, 16500 Prague 6, Czech Republic; hladil@gli.cas.cz・Marek Rǔžička, Academy of Sciences of the Czech Republic, Institute of Chemical Process Fundamentals, Rozvojová 135, 16502 Prague 6, Czech Republic; ruzicka@icpf.cas.cz・Leona Koptíková, the same address as the first author and Charles University, Faculty of Science, Institute of Geology and Palaeontology, Albertov 6, 12843 Prague 2, Czech Republic; koptikova@gli.cas.cz

The term "stromatactis" (stroma = Greek bedclothes, mattress, or anything spread out for sitting or lying upon; tactus $=$ Latin touch, touching with fingers, ?or taxis $=$ Greek arrangement) was introduced by the Belgian geologist Edouard François Dupont in 1881 (Dupont 1882). He first dis- tinguished between these and other calcite-filled objects in limestone sediments, although he explained them as recrystallized fossil objects. The horizontal arrays of single or reticulately interconnected stromatactis individuals typically occur one above another, being separated by sedi- 
ment devoid of stromatactis. The individual dish- or lens-shaped forms may have digitate to elkhorn-shaped projections on their upper surfaces. They often mark the mid-layers of moderately distinct beds.

Bathurst (1959) was probably the first to demonstrate that stromatactis were once cavities. Ideas about role of sediment dewatering in the formation of these cavities emerged several times (e.g., Heckel 1972, Desbordes \& Maurin 1974, Bernet-Rollande et al. 1981, Monty 1995, Aubrecht et al. 2002a, Woods 2002, Barbieri et al. 2004 or Wet et al. 2004), but the effect of this process was either considered to be of secondary importance (with projections of stromatactis or small stromatactis-like forms) or more connected to different types of cavities (zebra-limestone sheet cracks or overpressure fissures opened at bedding planes). Thus the term "stromatactis cavities" began in geology with a broad meaning, being more descriptive than explanative (e.g., Kukal 1971, Bathurst 1982, Dieken 1996, Neuweiler et al. 2001 or Neuweiler \& Bernoulli 2005), and was adopted for uses more directly related to the fields of hydrodynamics and rheology of the sedimentation of particulate suspensions through the application of experiments.

The present study directly continues this ground work about the formation of stromatactis cavities during rapid sedimentation (Hladil 2005a, b), in which the importance of specific compositions of particulate slurry suspensions is a key issue. There was found to be considerable consistency between the natural and experimentally obtained stromatactis shapes, including all of the relevant successions of changes in the sediment. These results are generally reproducible, giving reason to believe that this concept is viable. The specific sedimentation mechanisms we have found might considerably reduce the space for experimental verification of other interesting methods of producing stromatactis-type cavities, e.g., the syneresis maturation process of a particulate gel (Neuweiler \& Bernoulli 2005), internal erosion resulting from various agents (Matyszkiewicz 1997), the emptying of moulds from bacterial carpets (Flajs \& Hüssner 1993), or the post-sedimentary compaction of calcilutites capped by cemented material (Heckel 1972). Nevertheless, the commonly described relationships between stromatactis and mud mounds still clearly link a number of stromatactis to relatively quiet-water conditions below the fair-weather or storm wave bases (e.g., Bosence \& Bridges 1995, Boulvain 2001, Bourque $e t$ al. 2004), and some even to submarine hydrothermal vents (e.g., Kaufmann et al. 1999). These environmental considerations, whether completely or partly correct, might contradict the contention that the production of typical stromatactis cavities (with all their features) by direct sedimentation requires an abrupt (event) deposition of the material. Therefore, we expect that this new concept could also challenge basin geology to consider this possibility in reinvestigating the origins of mud mound structures. For example, every true stromatactis-bearing rock in the Devonian of the Barrandian area displays signatures of event sedimentation (e.g., allochthonous particles - Velebilová \& Šarf 1996, or absence of biostromes - May 2005), even though this process is currently less underestimated than in the past, as findings of erosional bases or clast imbrications at the bottom layers of these beds are not infrequent.

Although the production of stromatactis-like cavities during the sedimentation of somewhat specific and very complex polydisperse suspensions is an experimental fact (Hladil 2005a, b), there is a great deal more work to be done in this area. The key issue in the analysis of complex fluid-particle, particle-particle, and particle-colloid interactions with many controlling parameters is the unravelling of this complexity. The primary objective of this paper is therefore to dissect the complex problem of sedimentation-driven stromatactis cavities by selecting of individual constituents and experimenting with them separately. It is worth noting that the existing literature on the sedimentation of particulate suspensions is confined to cases involving relatively simple materials (with a few exceptions for complex polydisperse ones - e.g., Williams et al. 1991), and we are not aware of any previous papers that were focused on spontaneously-forming sediment cavities of the same type as shown in this and two preceding papers.

\section{A brief description of the basis for planning simplified experiments}

In explaining the reasons for designing the first experiments with simplified systems, it is important to summarize the direct observations that resulted from previous studies on very complex polydisperse systems of stromatactis-producing type (Hladil 2005a, b). High-speed filming, together with series of snapshots, allow broad and detailed descriptions of the structural and dynamic features that develop within the changing conditions in the vertical column as sedimentation progresses (Figs 1A-C). A description and commentary about the sedimentation of the common type of stromatactis-related slurries is the topic of next two sections.

\section{Fluid-escape and dynamic clogging effects}

The most significant stages of the sedimentation from turbulent, extremely polydisperse carbonate slurries (multimodal materials and medium dense suspensions; for compositional details see Hladil 2005a, b) corresponded to the deposition of a basal layer of low porosity, the evolution of a mottled mid-layer of the sediment with spontaneously-developing stromatactis-like cavities, and the formation of an upper layer with fine silt and mud (Fig. 1). The basal layer consisted mostly of compact grains of variable 


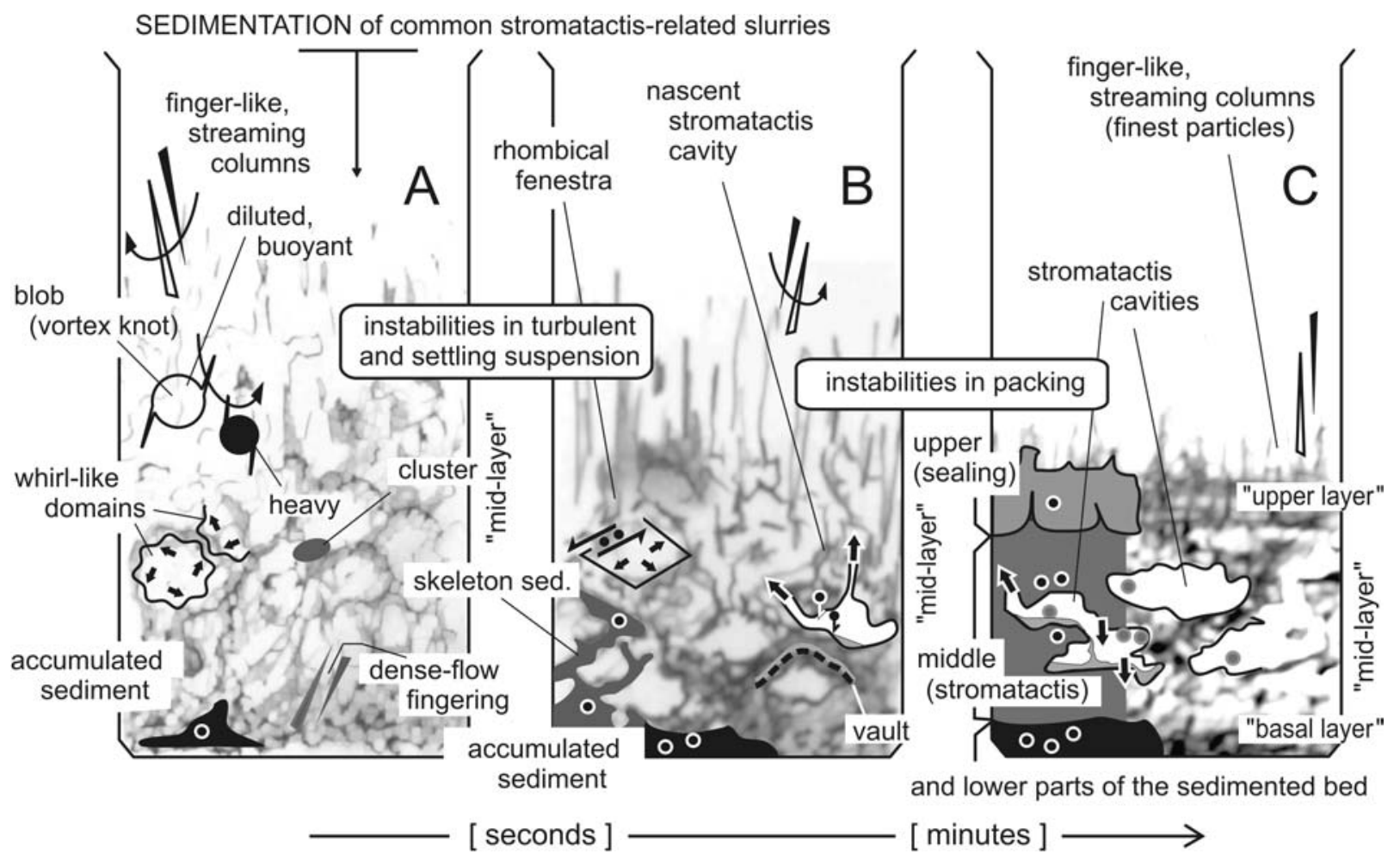

Figure 1. A simplified diagram showing the emergence and location of principal structures during sedimentation of the common type of stromatactis-related slurries. The observed structures were generalized on the basis of previous experiments using separate, 5 to $100 \mathrm{~cm}$ wide, cylindrical and rectangular vessels and troughs (Hladil 2005b). Here, this has been depicted as an experimental sedimentation in a $\sim 10-\mathrm{cm} \mathrm{diameter} \mathrm{beaker.} \mathrm{From} \mathrm{left}$ to right: earliest, transitional, and terminal (A, B and C) stages of this sedimentation. The finger-like streaming columns and also blobs (A) often drift, being inclined and wobbly in general. The vertical fingering pattern stabilizes only in very late stages and in the uppermost remaining parts of the suspension (C). The elementary segregation of grains that leads to the formation of clusters between the whirl-like domains develops quite early in the turbulent stages (A). The other structures (B and C) are either redescribed or newly described in the text summarizing these processes insofar as they are related to particle packing. The fluids escaping from compressed, slightly overpressurised fenestrae and nascent stromatactis cavities (centrifugal and upward arrows; B) are likely to be the most important factor, besides the friction- and density-related strengthening of the sediment skeleton and vaulting elements. The collapsing of the sediment under the most resistant vaults, together with internal sedimentation, have effects on stromatactis cavity shapes mostly in the terminal stages (downward arrows; partly B, but strongly in C).

sizes and distribution. The selective sedimentation of these grains was more comparable to being propelled down the turbulent system than of being controlled simply by gravitational sorting in suspension. When the base became deposited, the next zone up showed highly-evolving, mostly self-generated turbulence. This material formed a middle layer of sediment with a number of initial irregularities and voids of early stromatactis type. Higher up, the gradual thickening of the sediment layer was typically marked by numerous narrow vertical streamers. However, the upper layer, when formed, temporarily sealed the entire midlayer, thus preserving its water-swollen, holey structure with numerous stromatactis cavities.

The development of hydrodynamic instabilities (structure irregularities) in the broad middle part of the settling suspension would likely have significant influence on the final placement, density, shapes, and dimensions of the stromatactis cavities in the sediment. Although we can directly observe these changes during the process leading from the turbulent slurry to stromatactis-bearing sediment fabrics (Fig. 1), there are many open questions about the observable interactions, as well as the possibly others yet unidentified. However, in high-speed video records it was quite evident that the first zones with segregated large grains developed very early within a turbulent slurry, usually along the domain/domain or fenestra/fenestra shear boundaries (Figs 1A, B). The central parts of whirl-like domains typically contained the fine particles, whereas the larger particles were often concentrated at the boundaries between these domains. In these stages of slurry development, the patches dominated by very fine particles were easily to be discerned due to the opalescence (light refraction) of tiny particles. Meanwhile, the water confined within the narrow zones at these boundaries did not contain these opalescent particles, being clearer and flowing between randomly colliding and rebounding grains of larger than average sizes.

In typical situations, the evolution of these unstable, nascent stromatactis fenestrae developed more distinct out- 
lines with the emergence of the first grain-supported skeleton-sediment fabrics in the mid-layer of the settling column. The formerly unstable whirl-like shapes of the domains (Fig. 1A) changed into a diagonal network of rhombical fenestrae (Fig. 1B). The dynamic and relatively dense grain packing concentrated in the separating structures, whilst the generally diluted (low bulk density) suspension was still present in the fenestrae - as was readily discernible according to opalescence. The packing patterns of this stage were irregular and quite unstable, and this would be best explained by competition between the effects of suspensions escaping from the compressed fenestrae and strong dynamic (but not absolute) clogging of pores and channels around them due to centrifugal transport and settling of polydisperse granular material. In the emerging stromatactis cavities, the flow of the finest suspension particles finally produced coalescing systems of channels, the shapes of which resembled inverted trees. These shapes were visible until the upper ends of the collecting dewatering channels were opened to the turbulent suspension. At this upward moving boundary between the zones with and without skeleton sediment, the mouths of these upward openings fed small plumes of fine particulate material. Many of these channels typically propagated in diagonal directions, not straight upwards.

However, this "inverted tree" pattern of dewatering channels had a tendency to convert into a system resembling two mirrored trees when the thickening of the fine suspension reached the density that hindered the escape of fine suspensions. In this situation, the main fluid escape channels were not opened directly to the surface of the sediment, but instead had to ramify into overlying pore spaces. Nevertheless, the spreading of such sealing layers above individual stromatactis cavities and the entire stromatactis-bearing middle layer was not the only factor hindering the escape of fluids from this sediment. Fluid retention was also caused by the further aggregation, mixing, clogging, and packing of grains in thickened parts of the sediment between the stromatactis fenestrae. Besides the grains that became stuck in pores due to the pressure of suspensions flowing out from the compressed cavities, other grains were added to this mass by a sinking process, particularly after the general reduction of the escape of fluids. The once subtle skeleton-sediment fabrics became thick pieces of mottled sediment, but still preserved the stromatactis cavities. These cavities had nearly complete shapes, being horizontally flattened and showing the typical, upward-directed projections.

Thus, in most cases the stromatactis cavities directly proceed from the diagonal segmented fenestrae of the transitory skeleton-sediment stage (Fig. 1B), and these fenestrae proceed from the whirl-like diluted domains of the turbulent slurry in the middle layer (Fig. 1A). During this development of the stromatactis cavity precursors, the ef- fects of dynamic friction must gradually be replaced by the effects of static friction. The separating structures of skeleton-like sediment became thickened, accreted, and combined. Their post-sedimentation structures were mostly grain-supported (partly clogged, irregularly composed), porous but highly durable. The advanced stage of the consolidation of the vaults above the cavities was a significant moment that started the late, mostly rheologically-related changes. These domed vaults (compare the arching effects in granular materials, e.g., Hill et al. 1947, Duran et al. 1998, Michalowski \& Park 2004) were more often then not built in rough concordance with the previous stromatactis geometrical partition of the middle layer.

Under the complexes of neighbouring and coalescing vaults (arched structures), there often remained fluidized spots and zones that were slightly modified by additional partial settling, as well as channelled or diffusive infiltration of this material downward. However, these additional effects were observed usually at boundary conditions under which the stromatactis-producing systems still worked, but they were generally less important in the most typical systems. The majority of typically developed, complete stromatactis cavity systems tended to form diagonally arranged, irregular meshes of many individual cavities. Even the previous, classical papers emphasized this stromatactis tendency to have a reticulate distribution (e.g., Bathurst 1982). But in reality, the stromatactis cavities are much less regular. Each stage of their development contained some degree of instability, uncertainty, or generally chaotic features.

As indicated above, the very late stage of evolution of a sedimentary bed was always characterized by a considerably reduced number of upward directed particle-bearing streamers that moved upward in the sediment and then faded away. Consequently, the zones of low permeability above and below the mid-layer led to its considerable isolation. This isolation of the stromatactis-forming mid-layer is one of the important aspects of the entire process that is not yet fully understood. The critical point at this stage was related to the beginning of the downward movement of unfixed, mostly fine particles. It can also be considered as a sort of gravity infiltration of particles. Also, the remaining part of the internal, finest-particulate suspension uninterruptedly condensed downward, eventually blanketing the floors of stromatactis cavities with a snow-like cover (Hladil 2005b, cf. Neuweiler et al. 2001). Besides this nearly pervasive condensation, the downward-directed cascade jets (channelized flows) of fine material were also observed, being typically located in the most porous parts of the sediment between diagonally connected cavities. Even the vertical sealing by the latest layer of the sediment is limited. The experiments in which the sediment was aged up to six months ( $c f$. Hladil 2005a, b) showed fissures and faults that opened the circulation of pore fluids also in the vertical direction. This makes possible the further diagenetic 
modification of stromatactis and stromatactis host rocks, as is often (but not always) observed in natural stromatactis sediments - i.e., in cemented and/or recrystallised, uncompacted fine-grained materials, never in strongly compacted and stylolitised, micritic, laminar or nodular limestone beds (e.g., Aubrecht et al. 2002b, Hladil 2005b).

Under ideal conditions, the experimentally produced stromatactis cavities were remarkably resistant to gravitational collapse. However, such a situation corresponded to the optimum composition of the sediment where highly polydisperse, multimodal mixtures of variously shaped and internally different grains were basic requirements (Hladil $2005 \mathrm{~b}$ ), and the amounts of each $<0.063 \mathrm{~mm}$ (silt) and $>0.5 \mathrm{~mm}$ (coarse-sand) grain fractions were equal to $\sim 20 \pm 5$ wt.\% (e.g., Schmid et al. 2001, Hladil 2005b). Continuing this example with very common grain sizes, the fractions between $0.063-0.125$ and $0.25-0.5 \mathrm{~mm}$ were typically $\sim 15 \pm 5 \mathrm{wt} . \%$, and the richest fraction $0.125-0.25$ was $\sim 30 \pm 5 \mathrm{wt}$. $\%$. Such a "three-humped" distribution was generally found to give good results, even if we experimented with generally finer or coarser grain sizes. In addition to this, we must also take account of the dynamics and kinematics of slurries in contact with the substrate. In previous experiments, externally driven turbulent states for viscous (unsorted, undiluted) suspensions of medium density were preferred, but the lateral movement over the substrate was near zero, or rapidly decreased from $\sim 0.2$ to $\sim 0.002 \mathrm{~m} / \mathrm{s}$ within a few seconds. It was experimentally found that any strong changes in the basic parameters of relevant slurries, as mentioned above, led to the collapse of the stromatactis cavities or to the impossibility of producing them. This finding is not unexpected, because the stromatactis cavities are relatively rare structures in nature. For example, the reduced multimodality and/or increased sphericity of grains were the most significant factors inhibiting the growth of stromatactis cavities.

However, the occurrences of relatively large angular grains in stromatactis related sedimentary materials connect the above-mentioned review of the problem, and we yet have only a partial knowledge of what is involved in this. Therefore we decided to proceed with our investigation of the role of these relatively large grains in stromatactis-producing mixtures.

\section{The uncertain influence of larger solid objects (clasts, lumps, but particularly crinoid columnals)}

The presence of large grains, mainly crinoid ossicles, in stromatactis-bearing limestones has been either mentioned or directly documented in many papers (e.g., Dieken 1996, Kaufmann et al. 1999, Schmid et al. 2001, Wendt et al. 2001, Aubrecht et al. 2002a, Woods 2002 or da Silva \&
Boulvain 2004), though it seemed more like a coincidental than an essential feature of these sediments. Only Woods (2002) had written directly about encrinites. It remained unclear whether the large sand- to gravel-sized grains would be integrated in the formation of stromatactis cavities and how these particles could affect the final shape of the cavities.

Even the introductory experiments using a variety of settling slurries suggested that the critical conditions for the formation of stromatactis-like voids were considerably linked to degree of modality (and also polydispersity) in grain-size distributions, where particularly the presence of 20-wt.\% size-separated finest and coarsest fractions (relative to any mean grain size) were indispensable for the formation of rich stromatactis structures. Some, but not all, of the relatively large, roughly isometric-shaped and highdensity grains were occasionally the first objects to settle through the suspension. However, the mean-density (porous) and/or more complex shaped grains often remained in the stromatactis-producing mid-layers of the settling suspensions.

The video records of the complicated and variable trajectories of different particles indicated how complex these grain segregation processes are. This is particularly due to fluctuating hydrodynamic conditions, but is also caused by collision-and-clogging/interlock effects on grains. However, the first signs of localized spots with preferentially concentrated large grains were regularly observed early in the turbulent state of the stromatactis-forming middle layer. This could be explained by the presence of vortex structures ("whirl-like domains, vortex knots, or blobs") which concentrated the finest particles inward, toward the low-velocity areas. Only the extremely porous and wildly shaped low-density grains were retained in the inner parts of these domains, whilst the medium-density large grains were mostly pulled out, being concentrated in narrow boundary spaces where the domains were in contact. The effect of centrifugal separation of larger grains is apparently quite robust at low angular velocities and with sufficiently dense concentrations of particles. An analogy to this can be seen in recent studies of the segregation of large grains in granular mixtures (e.g., Awazu 2000, Aranson \& Tsimring 2005), though anyone can achieve roughly similar effects simply in creating vorticies by stirring a mixture of variously sized particles at the bottom of a glass of water - these are simple but inspiring experiments. Returning to the domains and the grains at their contacts, we can choose between two basic possibilities: either the domains are co-rotating or counter-rotating. The first possibility allows for the acceleration of grains, while the second allows grains to collide and cluster. The prediction of further changes of these rudimentary clusters of large grains is very complicated.

The first possibility is that the clusters of the largest grains provide a base for tightly-packed zones that can sub- 
sequently close the fluid-escape channels and roof a stromatactis cavity. However, this is possible only when graded grain-size distributions allow the effective clogging of pores and interlocking of grains. That this scenario is plausible has been confirmed by observations, but there are also many other possibilities. As a theoretical alternative, we can suggest that clogging can fail due to an over-limit size of these grains and pores. If this were the case, it would imply a shift of premature stromatactis windows up to this extremely coarse part, and this would cause unexpected and perhaps very dynamic effects in the re-concentration of fluids and particles. In another situation, the above mentioned premature stromatactis window could become significantly pulled away from a cluster. The cluster could then be broken, consequently abandoned, and filled by the surrounding sediment. Then, either a daughter stromatactis cavity could be formed, or coalescing cavities would result in a large cavity system. Although the photographically documented natural stromatactis structures suggest that these possibilities would likely occur for such materials, there remains much uncertainty regarding the mechanisms involved.

This analysis of these questions inspired a set of experiments that were designed to provide information about: (1) the possible capability of large angular grains to form interlocking clusters and stromatactis vaults, and (2) the interactions between sedimenting polydisperse granular materials with large grains resembling crinoid ossicles.

\section{Experiments}

Two groups of simplified experiments are described below, both of which focus on and the contribution of relatively large grains to the formation of sedimentary stromatactis structures. The first group of experiments covers the relationships of domical vaults and large angular grains themselves, whereas the second group is aimed at the assembling of large grains in a finer matrix.

\section{Particles and materials}

The natural, large, angular, and porous carbonate grains were substituted by cubes made by cutting blocks of hardplaster (technical brand name of the product: Spofa-Dental Mramorit Blue). Three different sizes of these roughly shaped cubes were used in our experiments: $\sim 5, \sim 3$, and $\sim 1.8 \mathrm{~mm}$. The wet-grain density (w.g.d.) of this material was $\sim 1990 \mathrm{~kg} / \mathrm{m}^{3}$. This value was selected because it roughly corresponds to possible intragranular porosities, including fissures, holes, pits and closed microcavities in natural calcite grains (i.e., the solid density of calcite, without this porosity, is more than $26 \%$ greater than this selected value). Several other components were added to sediment systems: yellow coloured alumosilicate beads (diameter $\sim 2 \mathrm{~mm}$, w.g.d. $\sim 1720 \mathrm{~kg} / \mathrm{m}^{3}$ ), black-coated glass beads (diameter $\sim 1 \mathrm{~mm}$, g.d. $\sim 2500 \mathrm{~kg} / \mathrm{m}^{3}$ ), a lowmodal, slightly polydisperse mixture of small angular grains of calcareous scoria (fraction 0.125-0.250 mm, w.g.d. $\sim 2020 \mathrm{~kg} / \mathrm{m}^{3}$ ), and a low-modal but highly polydisperse mixture of angular grains of limestone (fraction $0.010-0.750 \mathrm{~mm}$, w.g.d. $\sim 2680 \mathrm{~kg} / \mathrm{m}^{3}$ ). The reasons for selecting these sorts of particles are explained below, in relation to the individual experiments.

\section{Procedures and glassware}

The experiments with artificial granular materials were carried out in quasi-2-dimensional Hele-Shaw cells consisting of two polished plain-parallel glass plates $(0.2 \times$ $0.25 \mathrm{~m}$ ) that were parallel to each other and separated by a narrow gap $(7.5 \mathrm{~mm})$. Complementary experiments with the larger 15-mm-gap cells were performed only if doubts about the relationships of the quasi-2- and 3-dimensional were raised. The cells were filled by approximately 0.25 -volume mixture of grains, then filled up with water and hermetically sealed. We started by placing the particles randomly in the upper two thirds of the cell, using an irregular shaking method with tilting about subhorizontal positions. The mixing was eventually stopped, and the cell was swung to a vertical position in order to start the sedimentation. Further experiments with the sedimentation of more complex liquid-particulate mixtures were conducted using $250 \mathrm{ml}$ laboratory jars, where a $2: 3$ ratio of compact wet granular mixture to free water column was used. The closed jar was tipped upside down, and its contents were vigorously mixed using an irregular shaking motion. The reversal to position for sedimentation was done using a halfcircle trajectory, as fast as possible but with deceleration at the end. Each experiment was repeated at least 100 times, and the reproducibility of the results was evaluated using a series of photographs and high-speed video recording.

\section{Large grains and domical vaults}

Experiments with large cubes: The first set of experiments was focused on grain packing with the deposition of monodisperse material of 5-mm hard-plaster cubes in water. In the final stage the cubes of the largest size were arranged very regularly, having mostly long contacts and being linked in diagonal to subvertical, slightly curved rows. The subvertical rows occurred rather in the upper than in the lower parts of the sediment layer (Fig. 2A), and their average relative proportion was less than $15 \%$. They were found to be prevalent only in $\sim 1 \%$ of cases. Notwithstan- 

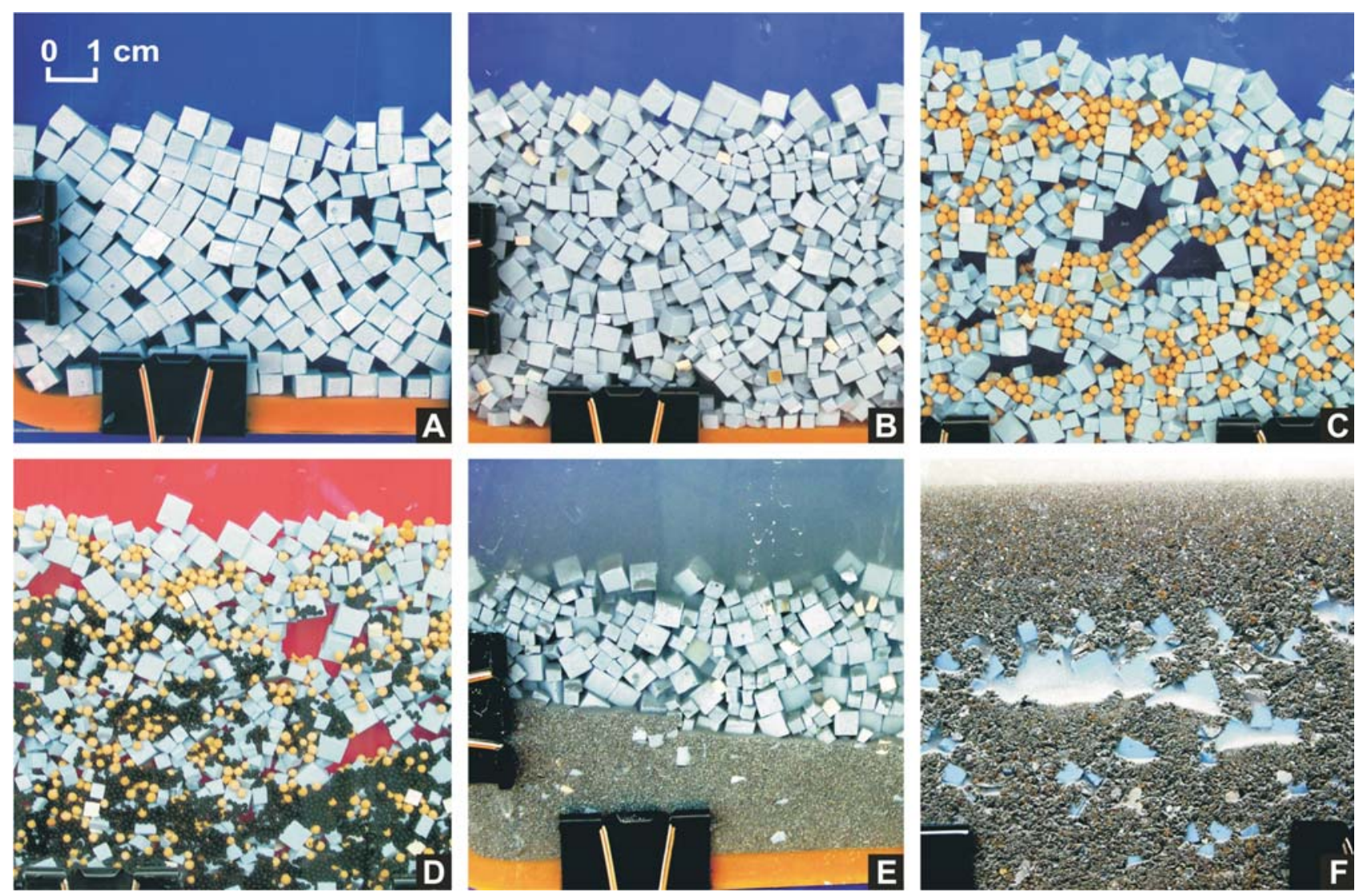

Figure 2. Large grains and domical vaults: Typical results of sedimentation experiments in quasi-2-dimensional Hele-Shaw cells with $7.5 \mathrm{~mm}$ gap between the polished plane glass plates. Solid particles in water (see the text for details about their composition). Snapshot windows are equally scaled; $1 \mathrm{~cm}$ scale is in upper left corner. Neither the monodisperse (A) nor the bidisperse mixtures (B) of artificial angular grains produced any significant signs that the large vaulted cavities would be preserved. However, the tridisperse mixtures (also if one or two components were replaced by highly textured beads of roughly equal sizes) were capable of producing cavities of this type (C). The production of similarly shaped cavities was reproducible even when a small amount of inhibiting particles was added (small smooth and heavy glass beads; D), until their amounts did not far exceed those shown in the picture (D). On the other hand, the tridisperse mixtures containing one component of a very different size were not effective at all (E). However, the addition of a bidisperse mixture of large angular grains into polydisperse matrix of nearly "zero stromatactis capacity" radically changes the aggregate behaviour of slurries, restarting the stromatactis-producing processes (note the cavities, still filled by opalescent internal suspension of finest particulate fraction; F).

ding 5-10\% of such cases in air, it was much more difficult to induce such subvertical geometry in water. This difference indicates the significant role of the viscosity of the fluid phase. The sizes of closely packed clusters of diagonally aligned cubes typically varied between $\sim 2$ and $\sim 6 \mathrm{~cm}$. Their boundaries with low-angle pores ended with $=5 \mathrm{~mm}$ openings at the points of intersection (Fig. 2A). The sedimentation of this monodisperse material did not produce any significant signs of durable arched structures above the cavities. Theoretically, it would be possible to set up a situation in which the neighbouring large clusters of cubes may form a solid vault, but the absence of both the underfed supply of grains and (or) collapse of small clusters in underlying locations do not allow for any of these cavities to be built. It can be concluded that the high angularity of grains in a monodisperse system would not create sufficient conditions for the production of stromatactis or stromatactis-like cavities.
Large and medium sized cubes: The very simple bidisperse system with roughly equal amounts of 5 and 3-mm hard-plaster cubes provided densely packed sediment structures (Fig. 2B), in which particle clustering led to the build-up of arrays predominated either by larger or smaller cubes. The sizes of these indistinctly separated arrays varied from $\sim 0.5$ to $\sim 4 \mathrm{~cm}$; the long axes of these arrays seemed to be randomly distributed with a slight tendency toward subhorizontal alignment in the lower and upper parts of the sediment, and diagonal to vertical alignment in the middle. The mid-layer also showed a slightly increased degree of clustering.

If compared, for example, with the driving-forces concept of pattern formation (Dzubiella \& Löwen 2002), the terminal stages of that sedimentation resembled a disordered state without any pronounced force field direction. This can be ascribed to limited lateral movement of the aqueous slurry mass and hindered water escape from the 
mid-layer. Generally, the act of clustering is usually regarded as being associated with energy loss due to particle-particle collisions, mainly if net dissipation is strong (Luding \& Herrmann 1999). In our case, this is probably related to fast deposition and strongly interacting material. Structural instabilities naturally developed earlier than during these late packing stages. These instabilities are typical of vertical sedimentation of mixtures that consist of grains of different sizes or densities, and they lead to the formation of interlocking, streaming columns (Weiland et al. 1984, Berres \& Burger 2003) or, if hindered and converted into convective structures, give to rise to "blobs" of selfcontained buoyant or heavy regions in the settling suspension (Batchelor \& Rensburg 1986, Berres et al. 2003). These features were observed in our experiments, although the relationships between these instabilities and the final clustering in the sediment are more complex. In addition, we should also consider marginal effects of final consolidation of the sediment, e.g., those slightly resembling the vertical (Breu et al. 2003) or horizontal Brazil-nut effects (Schnautz et al. 2005). Note that the imperfectly structured rows of 5-mm cubes often mark the sediment surface (Figs 2B-D), or other irregularities. The final 2-dimensional porosity is very low, around $\sim 7 \pm 2 \%$. Hence we can conclude that this bidisperse system with two particle sizes of highly angular has no capacity to form stromatactis-like cavities.

Grains of three different sizes: The sedimentation of tridisperse mixtures $(5,3$, and $1.8 \mathrm{~mm}$ hard-plaster cubes, roughly proportional amounts) produced completely different results. In this set of experiments, vaulted cavities were scattered throughout the broad mid-layer, being absent only in the basal and uppermost parts of the sediment. These cavities were usually $\sim 0.5-2.5 \mathrm{~cm}$ wide and $\sim 0.5-1 \mathrm{~cm}$ high. The locally accumulated large grains were found mostly above these cavities, i.e., rather at their roofs than on their floors. The vaults themselves seemed to be regularly connected with the presence of frictionally interlocking grains of all three sizes - clusters with dense grain-supported structure of maximum resistance against shear. Most likely, these specific patch structures were of primary importance in forming stromatactis-like cavities, due to their observed ability to be slowed down and joined together with diagonally aligned arrays of similarly behaving grains. This also causes an underfed supply of grains under the umbrellas of these structures. Subsequently, the formation of cavities was also aided by the collapsing, pouring, and infiltration of the smallest size grains into the porous sediment structures beneath the floors of the stromatactis cavities. These grains were also occasionally observed to form the downward-directed cascade-shaped streamers, particularly in places where the diagonally arranged cavities were connected by pores. Many cavities of stromatactis-like shapes were well preserved, even though more than half of the related vaults collapsed. The half-collapsed cavities remained open due to supporting pillars, which usually corresponded to one or two isolated large grains. The slightly decreased proportions of the largest grains, together with the increased proportion of smaller grain fractions, did not obstruct cavity growth, but rather enabled it.

What is probably the most important variation in these experiments was achieved due to substituting $1.8 \mathrm{~mm}$ plaster cubes for $2 \mathrm{~mm}$ alumosilicate beads. These beads are less dense than hard-plaster (by $\sim 13.5 \%$ ) and have textured surfaces. The general supposition was that these spherical particles can move more easily, and this would have been related to instabilities during sedimentation and, in the final stages, their easier gravity-driven penetration into the pores of the sediment. Concurrently, the high friction surfaces of beads did not preclude the possibility part of their involvement in the formation of densely packed, resistant clusters. The experiments confirmed that large stromatactis-like cavities were formed to the same or even greater extent than before (shadow holes in the sediment, Fig. 2C). Light textured beads supported the formation of buoyant "blobs" in the settling suspension ( $c f$. Batchelor \& Rensburg 1986), and they equally took part in the firm and poured/collapsed sediment structures (yellow beads, Fig. 2C). The broad, middle part of the sediment column was swollen in this way by $\sim 18 \pm 6 \%$. There only remained one question associated with the clusters and vaults above the cavities: It was necessary to decide whether the clusters and vaults are self-supporting structures or artefacts related to confinement between parallel glass plates. The answer was based on experiments in 15-mm-gap cells. The formation of cavities was reproducible again, though the shapes of the cavities in the middle part of sediment column were more 3-dimensional, and they resembled niches more than completely empty windows. Therefore, the effect of a narrow gap was not likely to be a critical factor.

These experiments suggested that such a scheme with three particle sizes would be a very useful basis for designing experiments for investigating the formation and stability of large depositional (primary) porosity voids. In addition, the video recording indicated that the supporting of vaults by the pressure of escaping fluids can precede the subsequent, umbrella and arching effects in advanced stages of the formation of the sediment.

The search for contrasting situations and the outlining of boundary conditions: An interesting question is whether the fenestral structures occurring in these sorts of tridisperse sediments are stable, or whether they can be easily destabilized or removed. Since we know that smooth and heavy spherical particles do not produce any stromatactis-like cavities under normal conditions, we can use these particles as an inhibiting component. These experi- 
ments were carried out with quadridisperse, quasi-proportional mixtures of 5- and 3-mm hard plaster cubes, light 2-mm beads, and smooth, heavy 1-mm beads. The conclusions from these quasi-2-dimensional experiments were that this amount of smooth and heavy beads reduced the total area of cavities only by $\sim 20 \pm 5 \%$ on average, and some runs even produced areas not smaller than before (Fig. 2D). Another experiment was conducted to determine the reaction of a bidisperse mixture of 5- and 3-mm hard-plaster cubes to nearly monodisperse fine-granulated particles (ground and sorted scoria). Such a slurry mix settled without any formation of fenestral structures, and the fine component filled the pores in the lower part of the sediment column (Fig. 2E). Yet the degree to which the clusters of coarser particles differed was only slightly reduced if at all (Fig. 2E).

Furthermore, a crucial aspect of our investigation was to study the interactions between these coarse grains ( 5 and 3-mm cubes) and a relatively fine, polydisperse granular phase (i.e., low-modal but highly polydisperse mixture of angular grains of ground limestone, $0.010-0.750 \mathrm{~mm}$ ). The latter material was prepared in several steps from ground limestone, particularly by removing both the fine dust and large clasts, and smoothing the modality to a minimum, exactly to the degree at which the mixture lost the ability to form small stromatactis-like fenestrae. It was important to closely approach this "zero stromatactis capability" in order to discern the effects of large grains from other sources of disturbance. The proportions $1: 2$ to $1: 3$ cubes to matrix were used.

The results were as follows: The clusters of packed cubes occurred irregularly in the lower to middle part of the sediment column. The largest clusters were arranged in arrays and took positions exactly in the middle height of the column. It was interesting that large pores without any matrix formed between cubes, and coalesced into subhorizontal cavities with flat floors. Typically on the lower sides of clusters, the stromatactis-like cavities were filled by a milky suspension of the finest particles (Fig. 2F), which generally resembles the situation in other moderately overpressurised, active cavities (e.g., between sand and mud - Peacock 2003), as well as the convective instabilities of settling across the density interface (e.g., Huppert et al. 1991, Hoyal et al. 1999) where the role of grain polydispersity is difficult to quantify, but undoubtedly influences the speed and extent of density differentiation and convection.

The last sedimentation experiments revealed that the large angular grains (cubes), when added to matrix material of strongly reduced (close to zero) stromatactis-forming capacity, can restore this capacity. In these experiments, the strong competition between fluid-escape and clogging effects produced stromatactis-like objects (using the Hele-Shaw cells, Fig. 2F).

\section{Initiating the growth of stromatactis cavity systems using the cubes and artificial crinoid columnals}

When we learned how to accomplish the transitions from the null to large-grain-accelerated stromatactis-forming stages in this way, it was possible to exchange the quasi-2-dimensional cells for laboratory jars in order to continue the experiments and to have more space for developing the stromatactis-like structures. The tridisperse mixtures that successfully produced arched structures and hollows were deliberately left out, as was the excess amount of fine silt, so that the experiments were handicapped by the absence of two very significant factors. We combined a bidisperse mixture of large grains and the above mentioned matrix, each of which have zero capacity to form stromatactis cavities. The proportion was $1: 3$, respectively. The large-grain bidisperse components were either cubes or columnals; a separate series of experiments was carried out for each type. The 5- and 3-mm plaster cubes were used for the first series of these experiments, and two types of ceramic, hollow cylindrical particles (brand name Steatite 502-900 and 504-410-C) substituted the natural, cemented crinoid columnals (dimensions of the latter: outer diameter of the cylinder, diameter of its central axial opening and its length $=4,2$ and $6 \mathrm{~mm}$ and 3,1 and $3 \mathrm{~mm}$, respectively. Small amounts of tracing particles were added in order to indicate the movements. These were yellow alumosilicate beads (w.g.d. $\sim 1720 \mathrm{~kg} / \mathrm{m}^{3}$ ) and blackish-grey poppy seeds (a little heavier than water), each of these particles $\sim 5$ vol\%. The granular mixture of these components with water was poured into a $250 \mathrm{ml}$ laboratory jar. A ratio of $2: 3$ compact wet granular mixture to free water column was used. Before sedimentation, the content of the closed jar was vigorously mixed (screw stopper down).

Using the cubes: Considerably large stromatactis-like cavities were produced throughout the entire broad, middle part of the sediment column, and the presence of these large pores caused the entire volume of sediment to increase by more than $25 \%$ (compare Figs 3A, B and next). The stromatactis-like openings formed directly in the clusters of large cubes, or close beside them, being developed mostly on their lower side. These spaces were free of polydisperse matrix, and contained only by a milky suspension of the finest particles. In accordance with the development of turbulent flow, and a certain degree of chaos in the process of sedimentation itself, the sedimentation experiments ended with hundreds of variations. This high variability was documented through the selection of typical structure patterns (Figs 3B-L). For example, the thickest and most interconnected systems of cavities were extremely irregular, especially in those parts where broad subvertical tracts contained only isolated wall bulges (Fig. 3B). The domical, concave upward shapes developed slightly above the middle of the 
sediment column (Fig. 3C and 3B in its upper part), and the swarms of underlying stromatactis-like cavities were often smaller. Some of the medium sized and small systems were irregular, forming a patchy zig-zag pattern, or standard multilayered swarms of such cavities (Figs 3D-F). Some systems also produced distorted arrays with nearly vertical segments of cavities in the upper parts of the sediment (Fig. 3G). But two patterns were found to be very significant. They concerned the mid-level interstices (coalesced rows of dish pore structures - Figs 3H-I) and reticulate systems with enhanced diagonals (Figs 3J-L). The fine suspensions confined in the openings were deposited as the first internal sediment, and these very fine particles usually covered the floors of principal cavities and their adjacent areas (so-called "snowing" - Figs 3I-J).

Although this case involving large cubes and "zero" matrix is specific when compared to the entire family of stromatactis-related sedimentation systems, many of the observed processes are common to all stromatactis-forming sediments. This concerns, for example, the conditions in particulate flows in nascent stromatactis cavities (centrifugally and upward-escaping fluids, Fig. 4A, and subsequently, the downward-directed particulate flows, Fig. 4B; compare also Fig. 1 for simplified general structures). The main difference from the common stromatactis cavity forming systems is that the relationships between the locations of the precursor fenestrae and the final cavities are not strong enough, as many cavities move, vanish, or expand in new places. In addition, the combined effects of arching in granular material and pronounced settling of fluidized material below the stabilized coalescent vaults are involved in these boundary conditions more regularly than in normal stromatactis producing materials.

Artificial crinoid columnals: The stromatactis-like cavities produced by sedimentation with columnals (Figs $5 \mathrm{~A}-\mathrm{L}$ ) were concentrated within the broad middle parts of the sediment column, but in many aspects their arrangements were practically the same as those that were produced using the cubes (Figs 3A-L). In common with the former experiments, the total volume of sediment increased by more than $25 \%$ in comparison with its highest possible bulk-density state (compare Figs 5A, B and next). We would like to point out that the large, concave upward shapes accompanied by swarms of smaller cavities below were also involved (Figs 5B, D). There was also a number of other patterns, such as the patchy to zig-zag forms (Fig. 5C), or multilayered (Fig. 5E), swollen, with isolated bulges of walls (Figs 5D, F), distorted, with subvertical projections (Fig. 5I), and also those that principally formed only one subhorizontal, coalescent level (interstice). However, the latter did not occur at the mid-level of the sediment column (compare the case with cubes - Figs 3H-I), but below (Figs 5G, J). Many combinations of random, patchy, and reticular-diagonal structures were quite typical. After allowing the "snowing" to settle for about 5 minutes, we found that besides large cavities a number of others were placed near or into the clusters of crinoid columnals. These small objects were pore spaces between individual columnals that remained free of coarser sediment matrix (Fig. 5L).

These latter two experimental modifications (Figs 3 and 5) simulated, with considerable fidelity, the shapes and arrangements of many (not all) types of stromatactis cavities as we are accustomed to see them in crinoidal stromatactis-bearing limestones. It is of further interest to note that these results were repeatedly obtained in boundary conditions where the separate components used for mixing the slurries were nearly inactive. We can therefore reasonably assume that using the fully active, highly polydisperse-multimodal matrix together with three coarse-grained and graded components would lead to the production of extremely spacious stromatactis cavity systems.

\section{Extended discussion with emphasis on comparison of experimental and natural sediments}

Research on stromatactis cavities covers a fairly broad range of concepts. Almost all imaginable aspects of sedimentary and diagenetic processes have been addressed (cf. Armstrong \& MacKevett 1982, Dieken 1996, Neuweiler \& Bernoulli 2005, Hladil 2005b). A number of possible mechanisms were connected with the effects of living or dead biota, and the remainder were derived from various physical and chemical processes that are or could be involved in the development of secondary porosity. The most re-

Figure 3. Large artificial cubes causing production of stromatactis-like cavities in otherwise non-productive matrix (polydisperse angular-grain material). Experiments in $\sim 6-\mathrm{cm}$ diameter jars; snapshot windows are equally sized; $1 \mathrm{~cm}$ scale is in upper left corner. The granular mixture in water reached its highest bulk density when subjected to irregular sharp lateral movements with slight vibrations (A). The thickness of the sediment deposited from suspension was regularly $\sim 25 \%$ greater than the minimum height (A: B-L). The results of sedimentation experiments depicted in this picture were selected from hundreds, and they illustrate the typical variety of stromatactis patterns (see the text for further comments on the individual pictures - relative to their vertical positions and arrangements in sediment column, bending of their floors, diagonal channels, etc.). Two snapshots (I and L) show internal sediment after 5 minutes from when the shapes of stromatactis-like cavities were stabilized: their counterparts, still filled by milky suspensions of the finest particles, are on the left. The relatively light tracing particles usually escaped upwards, but the remaining ones were either disseminated elsewhere (e.g., in sediment with the zig-zag or reticulate stromatactis patterns; E, J) or built into tightly packed clusters in vaults above the cavities (e.g., in the case of multilayered or mid-level interstice patterns; F and I). 

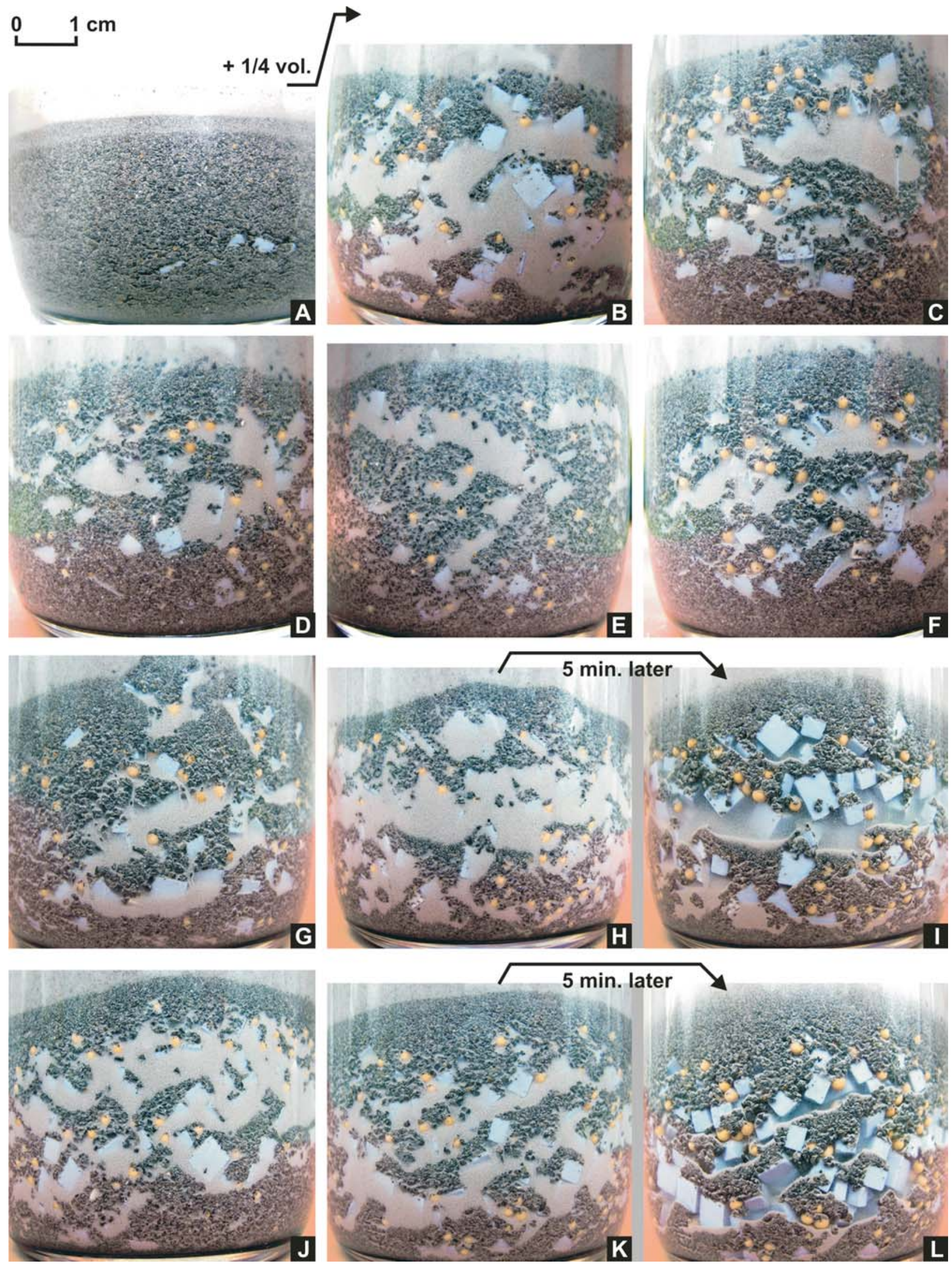

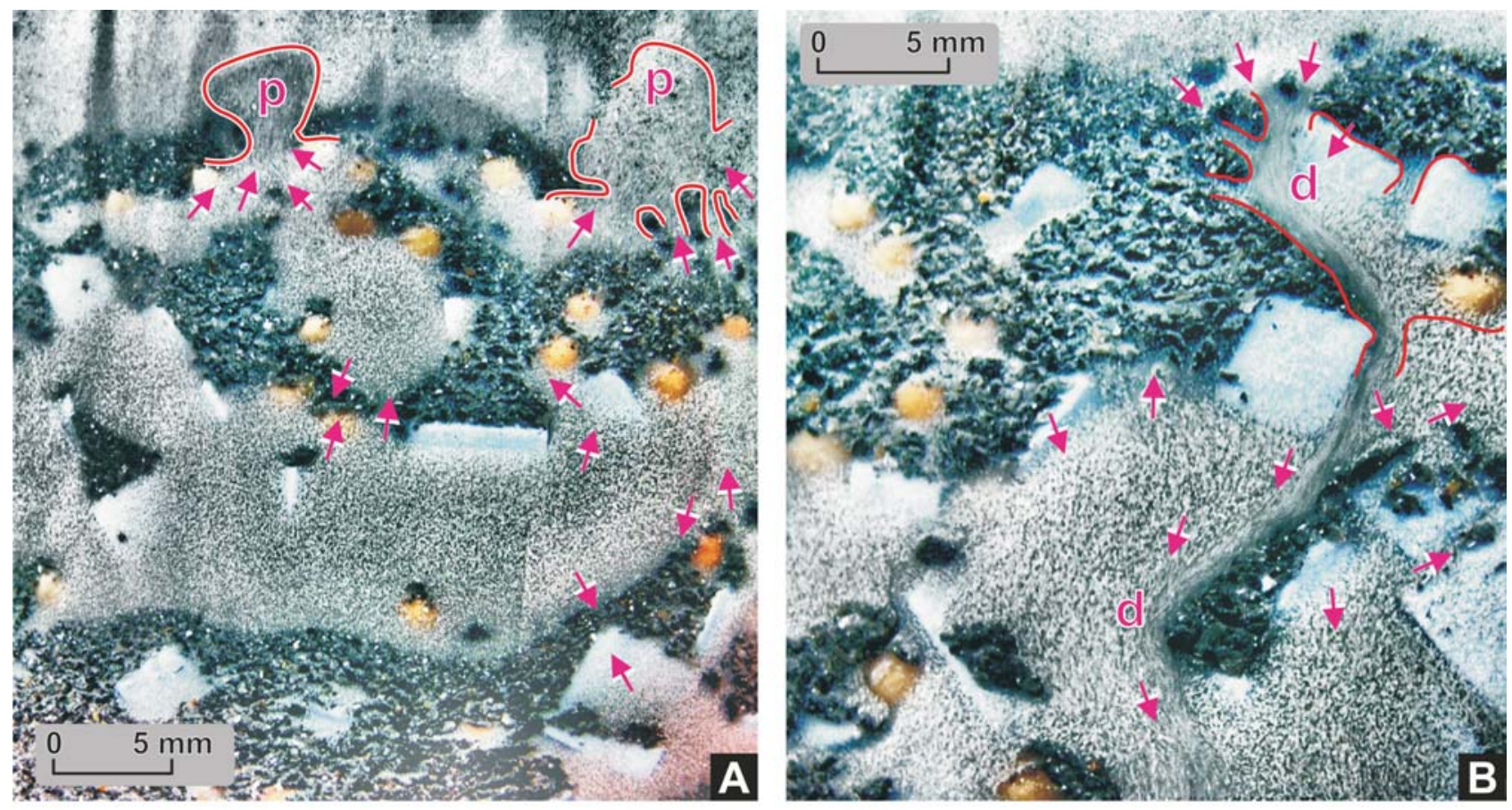

Figure 4. Two examples of nascent stromatactis cavities related to experiments with large cubes and "zero" matrix (experiments in 6-cm diameter jars; see text for details). The snapshot on the left (A) illustrates the terminal stage of overall water escape from these cavities. The particulate flows escape from compressed cavities in all directions, but mainly upward, where they form coalescing channels. The expelled material is either pushed into pores of the well-packed skeleton sediment (A, lower part) or penetrating the roof and forming the plumes (A, "p" in the upper part). The right snapshot (B) shows the early stages of subsequent processes when the pores in the grain-supported structure of skeleton sediment were sufficiently clogged and the settling suspension of the upper layer was sufficiently dense. The material in the cavities starts to flow downward. The downward-directed cascade jets ("d") can locally disturb the more complex settling and convection trajectories in the internal spaces.

cent direction in international stromatactis research concentrates on the decay of soft-bodied fossil organisms, mainly sponges, including bacterial and organomineralization processes (e.g., Aubrecht et al. 2002a, Bourque et al. 2004, Neuweiler \& Bernoulli 2005, Delecat \& Reitner 2005). This approach is usually put forward with the fact that there is great stratigraphic variation and incompleteness in the stromatactis record. Other studies seem to go back to universal diagenetic principles. According to Schmid \& Copper (2004), a combination of two previous models (Pratt 1982, Wallace 1987) seems most plausible, namely that sediments locally stabilized by microbial mats were internally eroded by lateral currents. The new, direct sedimenta- tion concept is entirely different from these two interpretations of stromatactis cavities, and the experimentally based theory also challenges much of the previous work on the environments and growth of stromatactis beds. The following discussion, therefore, aims to address the most controversial issues in this field.

\section{The partial overlap of stromatactis and crinoidal sedimentary facies}

Most typical stromatactis structures, without distinguishing between major and minor sizes (for large structures,

Figure 5. Large artificial crinoid columnals accelerating the growth of stromatactis-like cavities. Again, the fine polydisperse matrix itself had the capacity to produce these cavities at zero. The picture illustrates the variability of forms (selection based on 100 repetitions). Experiments in $\sim 6$-cm diameter jars; snapshot windows are equally sized; $1 \mathrm{~cm}$ scale is in upper left corner. Taken just after deposition. If compared with the cavities produced cubes, these systems involving artificial crinoid columnals were of roughly the same cumulative volume (i.e., again with an increase by 25 vol\%, or being swollen to little more; compare A, the sediment with the highest possible bulk density, with B and next). Also the shape patterns of the cavities were quite comparable (see the text for their characteristics relating to individual pictures; B-L). Although a high degree of analogy between the application of cubes and columnals was evident, the latter resulted in more complex cavity shapes. These cavities were more strictly confined to a broad zone around one-third to one-half of the sediment column height (e.g., D-F, G and H), and their coalescence into bigger systems of cavities is connected with the massive evacuation of light tracing particles from the middle to upper parts of the sediment. In this case, the prevalent number of documented cavities developed from clusters of artificial crinoid columnals, including the relatively small or abortive holes (L; a pair of snapshots made before and after "snowing" - i.e., after the first internal sedimentation of the finest particles). 

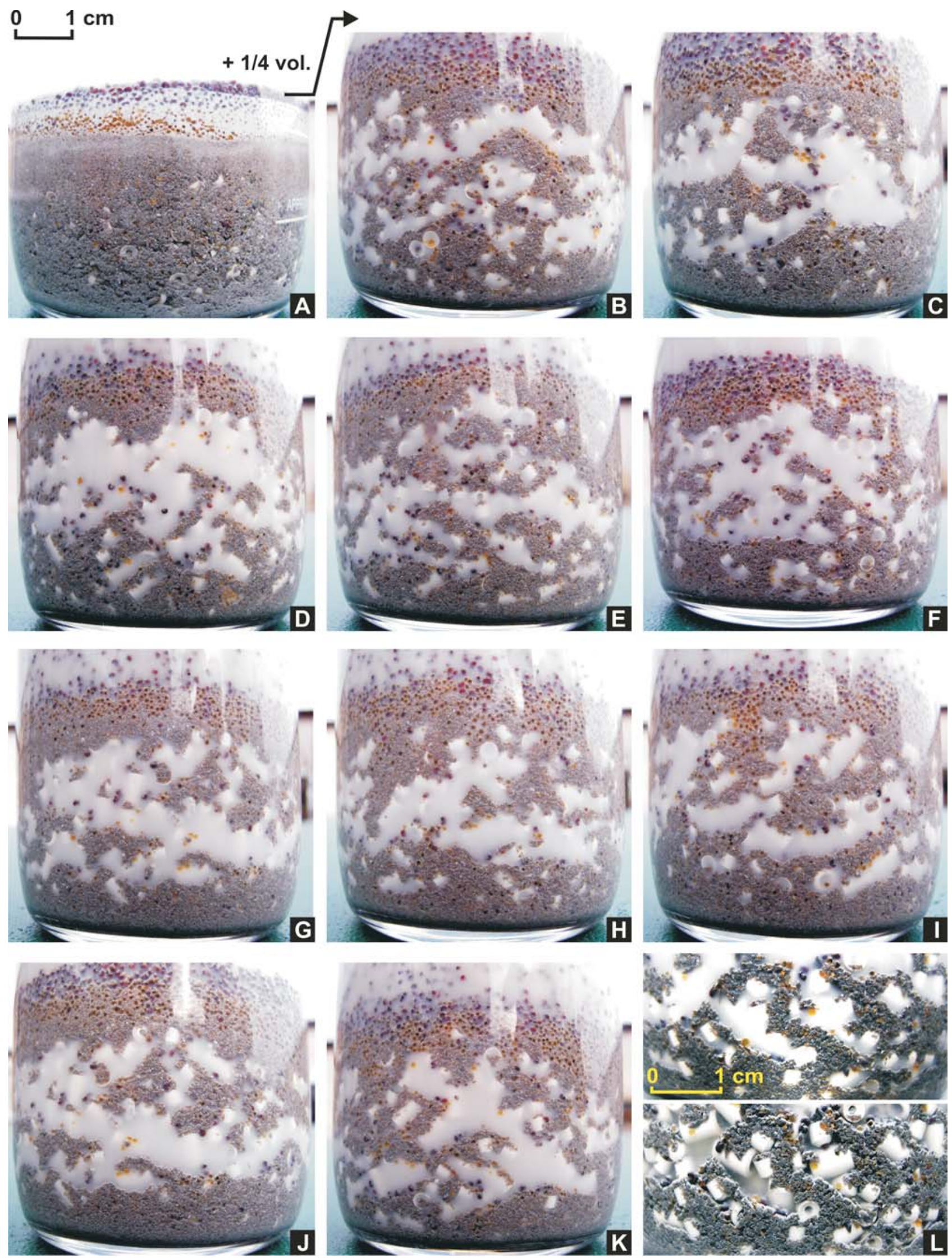
see Bathurst 1982; for microstromatactis see Gnoli et al. 1981; for sizes between several decimetres and several millimetres see Hladil 2005b), are related to a range of mostly subtidal lithologies where micritic nodular limestones alternate with poorly sorted calcisiltites/calcarenites. The former are typically affected by early diagenetic compaction and dissolution, having wispy solution seams, whereas the latter are well cemented rocks. And it is with the latter case in which there are grounds for expecting that stromatactis may occur if polydisperse, multimodal materials are involved. Sedimentary successions of poorly-sorted calcisiltites overlain by upward-coarsening packages of detrital calcarenites/calcirudites (and vice versa) particularly yield an increased number of these structures (Hladil 2005b). However, one precondition is that they were deposited from thickened turbulent suspensions of hindered movement and with loss of lateral speed. This is because of the generally verifiable negative correlation between the stromatactis and all other structures resulting from various types of unidirectional shear flow or high-energy traction deposition.

Furthermore, it is evident that many of large stromatactis swarms are found in the stratigraphic windows in which crinoid columnals are common components, as can widely be seen in mud mound related suites of carbonate sediments (e.g., Ordovician, Ashgillian age - Sivhed et al . 2004), Silurian, Ludlow - Simo \& Lehmann 2000), Devonian, Emsian - Dieken 1996, Frasnian - Boulvain 2001, Carboniferous, Visean - Wendt et al. 2001, Triassic, Carnian - Armstrong \& MacKevett 1982, Jurassic, Sinemurian - Neuweiler \& Bernoulli 2005, or Bajocian Aubrecht et al. 2002b). Some classic stromatactis localities also occur in stratigraphic contact with crinoidal limestone, often containing long pluricolumnals (e.g., near Suchomasty in Bohemia, Emsian - Fig. 6A, or near Clitheroe in England, Tournaisian - Fig. 6B), but these crinoidal banks almost never contain sizeable stromatactis structures. Only small to medium amounts of crinoid debris were appropriate for the formation of the largest stromatactis cavities (roughly $\sim 5$ to $35 \%$ ). At concentrations under $5 \%$, this component was largely substituted by parts from disintegrated sponges, bryozoans, or other complex shaped clasts or lumps ( $c f$. Tournaisian/Visean - Lees \& Miller 1995). The links between the presence of effective suspensionfeeders/filtrators (e.g., crinoids, sponges) and an abundance of fine-grained sediments are significant when we consider that the stromatactis-bearing sediments are poorly sorted materials in general. In the above described experiments (Fig. 5), the proportion of $25 \%$ of artificial crinoid columnals was optimum, but this was specifically for the subcritical matrices which otherwise had zero capacity to form stromatactis. Using the "supercritical" (stromatactis self-producing) matrix requires lesser amounts of admixed columnals for comparable effects.

\section{Stromatactis cavities in the subcritical matrix}

As mentioned above, we intentionally experimented with large grains and polydisperse matrices of nearly zero capacity to form the stromatactis cavities, because we aimed for separation of large-grain effects from other factors. Such artificial conditions caused problems connected with the search for natural counterparts, as the natural compositions of matrices are more complicated, and most of them are below or above this zero capacity. However, we can find natural counterparts that are comparable to the experimental results, and they are not so rare after all. As examples, we will consider the half-collapsed stromatactis systems from the Emsian Suchomasty limestone (Figs 6C, D) and Pragian Slivenec limestone (Figs 6E, F; see Chlupáč et al. 1998 for stratigraphy). In these two limestones, separate clusters of large and small crinoid columnals (Figs 6E, F) were embedded in stromatactis calcite cement. Hence the mechanical effect of crinoid columnals on accelerated stromatactis growth is not only demonstrable and consistently repeatable under experimental conditions, but can also be compared with natural examples, and we can reasonably assume that this sort of enhancement of stromatactis growth is generally significant.

\section{The ambiguity of defining the initial state of suspension}

The optimum empirically derived state of initial suspension (Hladil 2005a, b) corresponded to turbulent complex mixtures of roughly uniform, medium bulk density (and slightly increased viscosity). Although such a mixture works in experimental conditions, natural counterparts would need to be identified. We speculate that possible natural analogues should be searched for among particulate materials in vertical vortices in island wakes, as well as Langmuir supercells (Gargett et al. 2004) that are tens of meters deep, or in von Karman vortices behind any undersea obstacle and which may be combined with the effects of a complicated seafloor topography on the structure and energy of turbidity currents (e.g., at breaks in slope - Gray et al. 2005). In addition, the direct effects of driven turbulence on mixing are likewise important, because the settling stratified plumes or similar systems also have a great capacity to produce well-mixed and vigorously convecting mid-layers (e.g., Kerr 1991, Kerr \& Lister 1992, Cardoso \& Woods 1995, Hoyal et al. 1999, Blanchette \& Bush 2005). In the most simplified picture of the process, the basic precondition for this could be a layer of "suspended sand" capped by a thickening layer containing silt and mud. The assessment of appropriate sedimentation palaeo-scenarios would be inferred from sedimentary structures when beds are exposed in large outcrops and can 

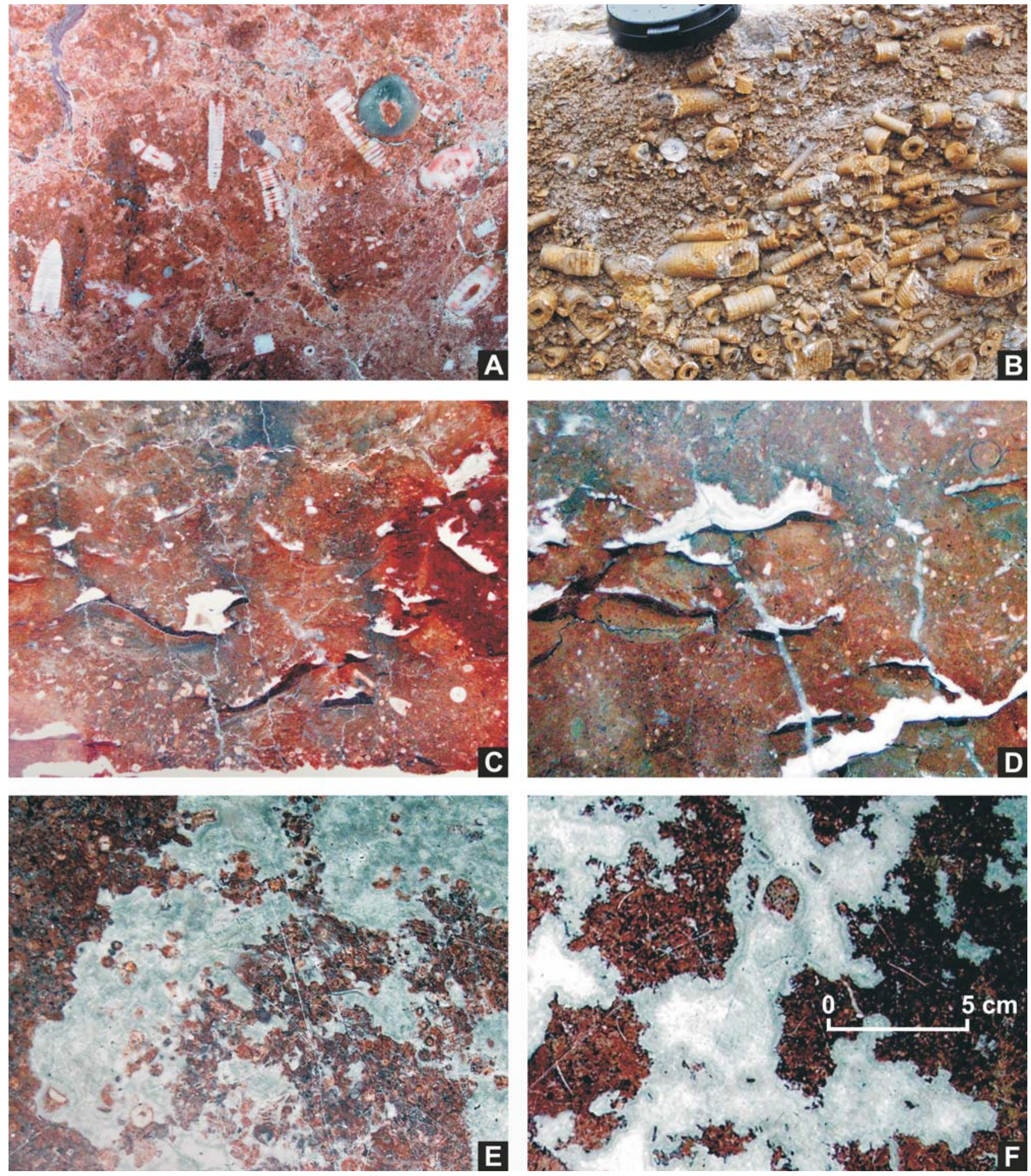

Figure 6. Natural particulate carbonate sediments with crinoid ossicles. Photographs are equally sized; $5 \mathrm{~cm}$ scale is in right lower corner. The stromatactis beds were often accompanied (preceded or followed) by banks with abundant crinoidal debris, also including non-disarticulated parts of crinoid stems: e.g., a subhorizontal polished section, Emsian Suchomasty Limestone, Barrandian Area, Czech Republic (A); or subvertical, weathered rock surface, end-Tournaisian Bellman Limestone, Clitheroe Area, England (B; photographs courtesy of A. Piechota \& M. Zaton). Variously scattered or accumulated crinoid columnals, once having been mixed together with polydisperse but rather low-modal fine-particulate matrix, are typically connected with half-collapsed stromatactis systems: e.g., two polished vertical sections, Suchomasty Limestone, Czech Republic (C and D). That the places within the sediments where crinoid columnals scattered and clustered were often the places where growth of stromatactis cavities began can be best exemplified by subhorizontal polished sections of the Pragian Slivenec Limestone (Barrandian Area, Czech Republic; E and F). Isopachous calcite fills of former stromatactis cavities are dotted by large columnals (E) or small ones, the latter in generally finer polydisperse sediment (F). 
be studied in three dimensions. However, there are two significant difficulties with these studies that aim to provide more than just superficial data: limited outcrop surfaces of relevant limestone beds, and an almost impossibly large volume of necessary thin sectioning.

\section{Relationship between stromatactis cavities and mud-mounds}

As already mentioned in the introductory paragraphs, the general links between stromatactis cavities and mud mounds can be seen as problematic when associated with experimental results about the significance of event sedimentation. A close relationship has been taken as evident in many papers (e.g., Bathurst 1980, Flajs \& Hüssner 1993, Bosence \& Bridges 1995, Hilali et al. 1999, Boulvain et al. 2004, Monty et al. 1995). In simplified terms, the occurrences of stromatactis cavities have been used as indicators of mud mounds, and vice versa. However, this apparent relationship should not be regarded as absolutely conclusive. For example, Bourque et al. (2004) concluded that only some mud-rich sediment accumulations might have the classic attributes of mud mounds. The basic difference was seen in the presence of small organomineralization-related carbonate particles instead of those that originated from biomineralization. The first are related to particles that may originate due to the presence of extracellular or decayed organic matter during the cementation of the porous sediment, while the second are related to the precipitation of carbonate as mediated by living organisms. However, the fine-grained interstitial carbonate precipitates are often abundant on carbonate slopes or elsewhere in perireef/ramp conditions (e.g., Wilber \& Neumann 1993, Webb 1996), where they may change originally mud-free sediments into muddy (micritic) units. The fine-grained precipitates that formed in the interstitial or bacterial mat spaces are far more common than previously suspected, even in a considerable number of stromatactis occurrences. On the other hand, the typical stromatactis cavities are absent in many autochthonous or allochthonous mudsupported carbonate mounds, even if these sediments have mottled or complex structures (e.g., Neuweiler et al. 1999). The distinguishing of local, proximal, and distal provenances of the fine-grained materials is not often possible, and many of these clotted/mottled structures give only weak evidence about the quality, amounts, and provenances of their allochthonous components.

Concerning the weathering resistant Devonian mound-like structures on the Maider Platform (Givetian Aferdou el Mrakib), Mounji \& Bourque (1998) suggested that flat beds with true stromatactis fabrics underlie rather than rim these knots of rocks, and the mound shape of these structures is possibly derived from "popping up of the beds" (op. cit.) related to large scale slumping. The rimming stromatactis beds were inclined after deposition, as evinced by their concordantly inclined geopetal fills. This further illustrates that there are considerable problems in current mud mound concepts. Besides event-sedimentation features in stromatactis-bearing beds, which are well documented and easily demonstrable in the quarries of the Barrandian area (Hladil 2005b), two other aspects related to secondary mud mound-like appearance have probably not been sufficiently covered in the existing literature. These concern the different post-diagenetical thicknesses of cemented and compacted/dissolved sediments and, consequently, the different rheological behaviour of relatively well cemented, thick and locally deposited beds during syndepositional and postdepositional detachments or displacements. Several authors came close to addressing this by indicating possible links to regional deformation structures, earthquakes, and hydrothermal venting, as well as re-entrainment, re-deposition or winnowing of sediment (e.g., Pratt 1998) or having doubts about mound shapes of the stromatactis-bearing beds (e.g., Mounji \& Bourque 1998, Aubrecht et al. 2002b).

\section{The controversy surrounding polymud fabrics in stromatactis-bearing limestones}

The classic polymud fabrics, as defined by Lees and Miller $(1985,1995)$ and modified by later authors, can result from complex sediment accretion processes ranging between in-situ precipitation of micritic particles (together with their mottled recrystallization, and their aggregation into packages of various meshing floccules, peloids, and lumps) and entrainment of biodegraded skeletal debris and stiff- to hardground fragments from the seafloor. Varying forms of bacterial coating, organomineralization, and cementation may result in the formation of soft, plastic, or firm covering carpets, or of embedded, isolated objects. The origin of successively nested fabrics is also possible, e.g., those related to internal collapsing, filling, injection, diapiring, fluidization, filtration, bioturbation, corrosion, cementation, and brecciation. Such structures may also contain many types of cavities, particularly the interparticle, shelter, collapse, particulate/colloid-, fluidor bubble-related fenestral, channel, fracture, and vuggy types. The absence of any in-situ frame-building organisms is characteristic of these beds (James 1984), although their redeposited remains may occasionally be found (da Silva \& Boulvain 2004, Hladil 2005b). A vivid description of such polymud conditions based on an example from the Early Carboniferous of the East Middlands of England was given by Gutteridge (2003): "If you could stand on the surface of a carbonate mud mound, it would probably have supported your weight up to a point. The 
rubbery mat may have broken and you would have sunk into the soft carbonate mud. Your legs would probably penetrate to knee depth with your feet feeling firmer sediment a few tens of centimetres beneath the surface." The presence of allochthonous material of various grain sizes was often mentioned in this context but never emphasized more than "suspensions baffled by crinoids". Similarly, little evidence of erosional truncations or presence of indistinctly marked (interlocked) bed surfaces without any clayey (dissolved) interbeds may have been used as arguments in favour of this concept.

However, in the course of considering all this evidence, a collection of facts emerges that do not contradict the event-sedimentation concept:

1. Lees \& Miller (1995, Fig. 32A, B) provided two vertical thin-section photographs of two basal parts of stromatactis beds. In these pictures, the basal bioclastic layers are overlain by stromatactis and microstromatactis midlayers (A, B). The mid-layer marked by large stromatactis cavities has an undulated and relatively sharp contact with the basal layer (due to vigorous instabilities and formation of large cavities), whereas the microstromatactis mid-layer has more gradual development. Hence we can say that these banks likely have both the bioclastic basal layers and mixed and mottled, stromatactis-bearing mid-layers.

2. The presence of upper layers is evident from the frequent descriptions of micritic/calcisiltitic and bacterial rubbery mats (see above, and compare Hladil 2005b, Fig. 11). And the presence of this upper layer itself, as well as occasional colonization of this surface by bryozoans, brachiopods, and crinoids (e.g., Lees \& Miller 1985, Gutteridge 2003), gives evidence about breaks in sedimentation.

3. It should not be surprising that such fine-grained unlithified bed surfaces beneath a lumpy or coarse-bioclastic basal portion of subsequently deposited beds directly relate to uneven, fuzzy, or co-mingled (obscure) contacts that are typically overlooked or discounted. Removal of the upper layer gives rise to even more complex interweaving, possibly leading to indistinguishable contacts. Some bedding planes are easily discernible, but certainly not all. The most useful way to identify the strata is to concentrate on horizontal arrays of stromatactis cavities, as they seem to be failsafe indicators of where the mid-layers of the beds are or were.

4. The stromatactis-bearing beds, due to characteristic granular (and colloid?) mixtures based on allochthonous and rejected material, have porous but relatively firm fabrics. After an initial stage of calm cavity microenvironments (e.g., Dieken 1996, Aubrecht et al. 2002a), the early diagenetic creation of pipes and cracks in the sealing layers (compare Hladil 2005b, Fig. 11) commonly allowed the circulation of marine pore water and relatively fast cementation (e.g., Kaufmann \& Wendt 2000). This partial breakage caused by the aging of the sediment lead to the deposition of the next internal sediment. The remaining cavities and crevices of any type were often filled with calcite spar, usually in shallow burial environments under strong fresh water influence (e.g., Bourrouilh et al. 1998). The underlying, overlying, or surrounding skeletal or mud-dominated "normal" calciturbidites differ in structure and composition: imbrications at base, plane parallel laminae, massive or rippled subdivisions, and sutured contacts formed by the more spherical, slightly better sorted and tightly packed particles. Wispy seams and solution residues concentrated at bedding planes. The primary thicknesses of these beds were significantly reduced by compaction.

5. A fundamental question that remains to be answered is the observable affinity of repeatedly accumulated, patchy stromatactis-bearing beds to certain areas on the slope, at least for some time period (discussed above, e.g., possible role of breaks in slope and consequent formation of co-mingled plumes derived from gravitational flows).

Therefore, the natural sedimentation regimes in relatively restricted areas with stromatactis beds still remain open for further research. On the other hand, it is also possible that this system is nothing more than a very simple reflection of place-related compositions in carbonate turbidity currents or plumes of any origin - and that all other differences are a consequence of this.

\section{Possible causes of the stratigraphic variation and incompleteness of the stromatactis record}

Recent reviews related to the importance of true stromatactis structures through time (e.g., Neuweiler et al. 2001) suggest that they are common in the interval between the Ordovician and Carboniferous, with particular peaks in the Devonian and Carboniferous periods. They are less abundant in the Cambrian and Permian strata, with only limited occurrences in the Mesozoic era. The pre-Cambrian and post-Mesozoic stromatactis structures seem to be either extremely rare or completely absent. Many of Mesozoic stromatactis cavities were preserved in different ways, because the richly developed sediment infilling the cavities greatly reduced the space for calcite spar (so-called aborted stromatactis, see Neuweiler et al. 2001). These distribution characteristics are undoubtedly important.

The classes of relative abundance definitely require further explanation (including terms like abundant, common, sparse, or rare). For instance, the Devonian calciturbidite sequences of the Barrandian area can exemplify the abundant stromatactis populations of the Lower and Middle Devonian epochs (there are numerous accessible exposures, see Hladil 2005b). But in reality, the calculated values for relative volumes of stromatactis-bearing strata are as low as $\sim 1.0 \pm 0.5 \%$, with microstromatactis-bearing rocks being only two-three times more frequent. These lev- 


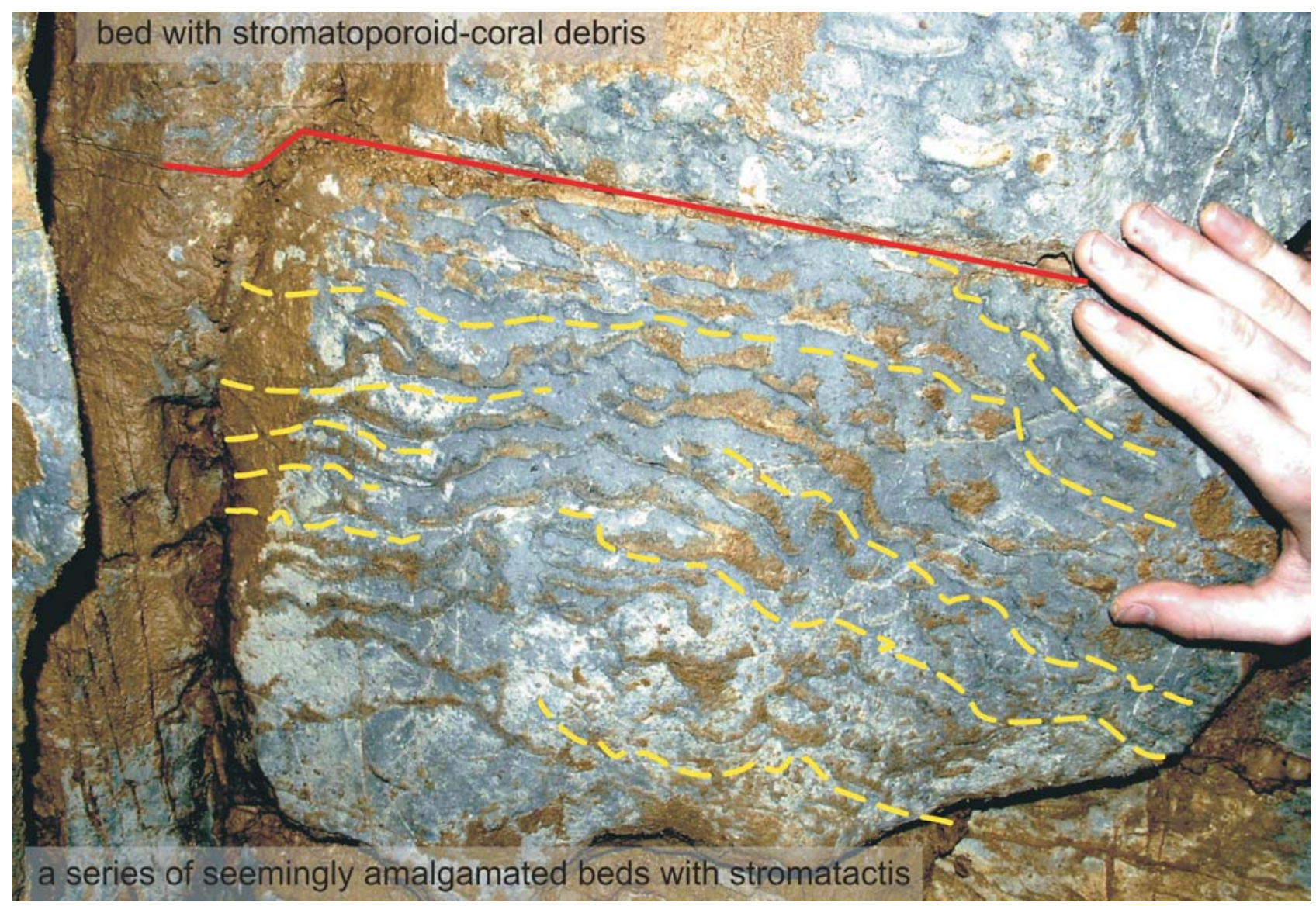

Figure 7. A very new, previously unpublished example of stromatactis structures from the Middle Frasnian (Upper Devonian) limestones of the Moravian Karst. The fine-grained, polydisperse and multimodal (also with scattered crinoidal debris) calciclastic material with stromatactis was deposited in a depression indented into the frontal margin of a reef, and the topmost part of this early lithified unit was truncated and covered by redeposited rubble and sand containing corals, stachyodids, and disarticulated crinoid columnals of millimetre dimensions. The stromatactis shapes mostly correspond to multilayered swarms or mid-level interstices (coalesced voids in rows), and only some of them are well-separated and reticulately arranged. The mostly isopachous, crystalline spary calcite mass is often (not always) browned due to former contact with cave fill. The discovery of this section also suggests that scattered stromatactis occurrences can be randomly found in well-known limestone complexes where the previous search for such sediments was incomplete. This photograph was taken in the Crystal Corridor of the Svážná Studna Cave, in the upper part of the Lažánky Karst Valley (author J. Otava, 2005).

els and patches are mostly confined to mid-Pragian and Late Emsian intervals, and to facies corresponding to breaks at various depths in the upper parts of carbonate slopes (? 40 to ? 600 m). The proportion of preserved stromatactis beds naturally depends on what has been preserved from tectonic forces and erosion. The present mud mound databases (e.g., Krause et al. 2004), involving similar and often dissimilar rocks, are indicative of several comparable world-wide Devonian occurrences:

1. North Africa (Morocco and Algeria, with the connections via Sardinia, Carnic Alps, to the Barrandian area in Bohemia, or to Montagne Noire in France);

2. NW Europe (mainly Dinant synform in southern Belgium), and less frequent and less pronounced stromatactisrelated beds in Germany (Rhenish-Harz basinal facies, and their continuations in southern Poland and Moravia - e.g., the newly-found occurrences in the Moravian Karst, Fig. 7);

3. and finally a few occurrences in western Canada (Al- berta), western Australia (Caning basin), as well as in Asia, where these rocks were poorly assessed in general.

It should be noted that these occurrences are few and far between, and they are available to us for two reasons. First, the Devonian carbonate sedimentation areas were extremely large, the thick limestone deposits of which contained considerable amounts of very fine material. Their slopes were often gently inclined, being covered by thick calciturbiditic series, and bacterial mats probably covered large parts of the upper-slope seafloors. Second, later tectonic segmentations and uplifts preserved some miniature segments of the above mentioned huge slopes. It is worthy of note that the uplifting/denudation of these structures happened very late, usually over tens or hundreds of millions of years.

Completing the brief digression about quantification, we now return to the question of why this distribution arises. The stratigraphic distribution of well-preserved, true stromatactis structures, if compared with various 
fluctuations of principal environmental factors, shows a correlation to changes in ocean water composition (aragonitic/calcitic seas - e.g., Mackenzie \& Pigott 1981, Sandberg 1983, Stanley \& Hardie 1998, or $\mathrm{MgSO}_{4}$-rich $\mathrm{CaCl}_{2}$-rich seas - e.g., Lowenstein et al. 2003). Calcitic, $\mathrm{CaCl}_{2}$-rich seas emerged during the Cambrian, and were richest in places of stromatactis abundances. The opposite situation was not favourable for stromatactis carbonate sediments. Less pronounced but still interesting is the correlation of these increased abundances with greenhouse-calcite seas and high sea level (e.g., Steiner 1967, Sandberg 1983). Hence, the stromatactis occurrences seem to be roughly linked to calcitic, $\mathrm{CaCl}_{2}$-rich seas, greenhouse conditions, and extremely high sea levels in general. However, in terms of detailed stratigraphy, they eluded the maximum highstand conditions, preferring rather the moments of partial sea-level falls (regressive periods) or those at lowstand/transgressive system tract transitions. This is also the best explanation of their becoming naturally embedding under the debris from the reefs, fore-reef bioherms or just after the periods of sediment starvation on the slope. The combination of these factors may have many relevant consequences. For instance, the mechanical abrasion, dissolution and sorting of grains was reduced in general, a considerable amount of very small (micritic) grains was still produced and preserved, the huge carbonate slopes were often gently inclined and tentatively covered by bacteria, but slight sedimentary starvation supported the formation of various stiffgrounds/hardgrounds as well as low-frequency calciturbidite shedding. Also important is the generally prevailing, $\mathrm{CaCl}_{2}$ /calcitic conditions that were most likely little perturbed due to these partial regression events, still having sufficient potential to produce calcite spar.

This may provide a tentative explanation for the stratigraphic variability of well-preserved stromatactis structures in limestones, although it implies fewer constraints on the stromatactis sedimentation processes themselves. Thus we can suppose that various collapsed, filled, or distorted stromatactis-related structures could also be found in carbonate sediments of non-stromatactis ages, or even in non-carbonate sediments that were suddenly deposited from particulate suspensions of appropriate compositions.

\section{The main traditional counter-arguments: answers to the most frequently asked questions}

1. How significant is the effect of walls in experimental vessels when compared to natural conditions where sedimentation is less confined or seemingly unconfined laterally? Can we actually say that the quasi-2D and small-size (cm, dm) 3D sedimentation experiments can mirror the natural processes (e.g., substituting complex longitudinal stress in sediment by the conditions at smooth walls of jars or tanks, or reducing the angle of rotation and speed of particles using the Hele-Shaw cells)?

Nearly all hydrodynamic experiments carried out in cells, tubes, and vessels may be biased in this way. During the first experiments (Hladil 2005a, b), the sediment deposited in the vessels was subsequently deep frozen in liquid nitrogen and sliced, and the cavities inside the bed were roughly of the same size and shape as those occurring in contact with the walls. Other corroborating evidence that this is the case comes from comparing the percentage of cumulative large-cavity areas (on sides of the vessels) with the swelling of the whole bed. The large cavities occupy about $20-25 \%$ of the lateral face of the bed, and the whole bed is swollen by $25-30 \%$ relative to its artificially compacted volume (e.g., Fig. 5). The small percentage differences are to be expected given that the formation of stromatactis cavities is irregular, and that small cavities are scattered in this material as well. The situation is more complicated in the narrow, quasi-2D cells (Fig. 2). Here, the sedimentation of largest particles sometimes produce larger cavities than in 3D (Figs 2C, D). However, the mixtures of subcritical matrices with large grains produce less complex, sometimes less spacious, stromatactis-like cavities than in 3D (Figs 2F, 3). Hence, these quasi-2D systems might show increased effects of internal stress and arching, while the formation of typical pre-stromatactis domains and fenestrae would be slightly suppressed. But the main finding of these various experiments is the demonstration that the described processes are robust enough to cope with different sizes of sedimentation cells (from centimetres to metres, with to the possibility of producing the largest stromatactis cavities using sedimentation cells that are several metres wide).

2. How we can compare the structures obtained from experimental sedimentation with the natural ones that were modified by diagenetic processes (e.g., corrosion, cementation, compaction, or recrystallization)? Can we ever be sure that stromatactis are principally sedimentary structures when many authors have focused on their post-sedimentary diagenetic features, diversification, and a wide variety of specifics?

Yes, because many natural stromatactis systems are well preserved and contain all of the diagnostic features of rapid sedimentary processes of this type (polydisperse-multimodal material; distinct lower, middle, and upper parts of the beds; characteristic shapes and arrangements of the large, mid-layer cavities; complex infiltration, washing and "polymud"-like mottling of materials in the sediment between the stromatactis cavities; the fine internal sediment from "snowing" in the cavities; for further details see Hladil $2005 \mathrm{a}, \mathrm{b}$, and the introductory chapters in this paper). These stromatactis sediments are comprised of considerably stable (although porous) mud- to sand-size particulate materials. 
As experimentally confirmed (op. cit.), the structures with coalesced cavities or flat cavities with pillars may survive for several months or longer, which means, in natural conditions, until the sediment is stiffened by recrystallization-cementation (in finer varieties) or cementation (in coarser varieties). If these sedimentary structures contain material other than this stromatactis related material, stromatactis cavities might not be generated, at least in a durable form (e.g., the compactite-type, nodular limestones between some stromatactis bed successions - Aubrecht et al. 2002a, b). And when cementation does not sufficiently harden the sediment, it favours subsequent collapse or complete filling with infiltrated sediment. The diagenetic alteration of stromatactis swarms depends on many circumstances and conditions. The smallest and most highly separated stromatactis cavities are mostly filled by bladed or mosaic calcite cements. The large and interconnected swarms of cavities show all the attributes of having been altered by solution-channel porosity systems for months or many years, during which time they tended to be (and usually were) either temporarily corroded or quasi-continuously filled by isopachous cements. The existence of this channel-and-cavern porosity is corroborated by many examples of the episodical deposition of infiltrated internal sediments. These and other possible changes greatly embellish the stromatactis formations in nature, but have only secondary importance for the original systems of these highly specific cavities and their host rocks. The stromatactis cavities must have been formed early during sedimentation due to presence of the sediment related to "snowing" at the first moment after the deposition of the bed, as all collapses of grains or vaults, changes caused by bubbles, tensile shrinkage and the formation of hydraulic cracks, as well as those from recrystallization, corrosion, and cementation stages were formed as a succession of younger phenomena which overprinted, modified, cut, or covered the older ones.

3. If all these stromatactis-bearing strata are explained as sediments of very specific, rapidly settling suspensions (as a sort of event deposition), why were so many of them below the storm wave base (e.g., Boulvain 1993)? And why the coalescent nearly metre-sized stromatactis were replaced by smaller ones close to the strom wave base?

Most of the stromatactis-bearing strata must have been formed below the storm wave base, because the experiments suggest that the formation of these cavities is related to rapid subvertical settling of highly specific suspensions. The relatively dense surge of deposited material must have nearly stopped before the sedimentation of the bed. Any rapid movement of this settling material along the seafloor could cause the absence of the stromatactis structures, and the sediment would be deposited as a calciturbidite of common type, e.g., with imbricated basal part and parallel-laminated, homogenized or rarely rippled middle and upper parts. The effects of deep turbulence related to storms of extraordinary magnitude would also be limited, because the stromatactis bearing sediment was, most likely, durable (porous and brittle), but not so much as to completely resist the effects of vigorous pressure fluctuations or erosional events. We considered the physical state of suspensions (and possible places for this sedimentation) in the Discussion section of this paper. The stromatactis strata that contain giant stromatactis could correspond to giant clouds of this material with abundant components recycled from deeper carbonate slopes. Consequently, the smaller $(\mathrm{cm}$, $\mathrm{dm}$ ) stromatactis could correspond to smaller clouds that have components from an upper part of the slope. This is consistent with many observations, and does not contradict the explanations made according to hydrodynamic-sedimentation concept.

4. Why do we disagree with the models of the stromatactis as cavities formed after decayed soft-bodied organisms (sponges - recently again considered by Delecat \& Reitner 2005), or clumps of mucilaginous aggregates from seawater ( $c f$. Precali et al. 2005) or the sediment itself (cf. Aubrecht et al. 2002b)?

The ideas behind these concepts are generally as follows: Most of these organisms and clumps of extracellular matter are composed of about $90 \%$ of water, which is, however, unable to escape until the decay of these objects. The cavity ceiling would be supported for longer time against collapse, providing time at least for partial cementation. And the fluids released after decay can form post-sedimentary structures related to fluid escape, the accumulation of bubbles, corrosion, and the formation of channels with subsequent transport and deposition of internal sediment and the precipitation of cements. It is certainly possible to imagine or experimentally study such conditions. Nonetheless, these concepts about the burial of ubiquitous soft-bodies involve major problems that can be easy identified. Soft-bodied, bulky sponges of bulging shape occur frequently in carbonate sedimentary environments, colonizing mainly the seafloors of lagoons, and other environments on reefs, but particularly the deeper parts of outer slopes. The remnants of sponges buried rapidly within mud-rich calciturbidite sediments can be traced elsewhere in the Phanerozoic sediments of the world, but they almost never support ceiling arches in the sediment. Only a few documents include evidence of more complex sponge remains surrounding or meshing the nests with stromatactis cavities (e.g., Bourque \& Gignac 1983, Shiraki 1996, Neuweiler et al. 2001), or of the possible shrinkage of sponges and their transformation into stromatactis-like cavities (e.g., Delecat \& Reitner 2005). These sponge-oriented rely on the weak causal relationships and negative correlations between the density of accumulated sponge skeletons and the occurrences of stromatactis cavities. In general, accumulated or buried sponges are mostly found in non-stromatactis beds, 
whereas the typical stromatactis limestone beds are characterized by the presence of polydisperse-?multimodal, basically muddy, silty, and lumpy matter combined with a significant admixture of large and/or complexly shaped sponge spicules. Hence, it can be suggested that spongebacterial conditions are better sources for resedimented stromatactis-producing materials than are the places of in situ "sponge to stromatactis" change. Mucilagenous megaflocs and clouds in seawater are not very commonly seen to be embedded in abruptly sedimented beds, as this would be possible only in combination with pycnocline-related, mucilagenous "false bottoms" (cf. Precali et al. 2005) or mucilagenous "blankets" on the seafloor. The latter possibility was carefully studied and tested for the case of the Emsian (Lower Devonian) stromatactis sediments (e.g., Flajs \& Hüssner 1993, Dieken 1996), but these studies have remained inconclusive.

\section{Conclusions}

The formation of mottled fabrics combined with the presence of stromatactis-type cavities in the mid-layer of instantaneously deposited beds seems to be a direct consequence of slurry composition. Relevant particulate slurries must be highly polydisperse (and multimodal), containing particles of angular shape or with highly textured surfaces. The presence of $\sim 20 \mathrm{vol} \%$ fraction of extremely fine grains, and roughly the same proportion of larger sizes, can significantly contribute to the formation of the largest cavities. The externally or density driven convective processes in these relatively dense, heterogeneous suspensions are likely only to form the large, increasingly structured domains that can be further transformed into rhombical fenestrae and finally, in the terminal stage of the sedimentation, into a system of durable, collapse resistant stromatactis-type cavities.

At least three significant aspects of this process are worthy of mention: First, the formation of high-density clusters and the segregation of relatively large grains at the boundaries of domains and fenestrae are important prerequisites for the development of initially unstable sediment skeleton structures. Second, the transformation of the fenestrae to stromatactis-like cavities can be characterized in terms of the competition between fluid escape and dynamic clogging effects. The latter gradually takes a major role in the system, and the internal sedimentation from residual suspensions dominates the mid-layer pore flow patterns at later stages. And third, an essential role is played by compressed cavities. They contain slightly overpressurised fluids which tend to escape, but the grains expelled together with these fluids are stopped in the surrounding pore spaces. The structures in typical stromatactis-producing materials are only little affected by the rheological arching and differential settling of the material below sheltering arches. This is typical for stromatactis cavity formation at boundary conditions. In general, the rapid sedimentation production of stromatactis cavities is a very complex, quite variable, and vulnerable process, and it is principally due to a number of variables that can affect the behaviour of slurries (e.g., sizes, shapes, and grain density of particulate material, or presence or absence of organic matter, colloids and perhaps also microbubbles).

Much experimental work must be conducted to assess these aspects of the system. However, several types of experiments performed in the present study allow us to conclude that individual aspects of this complex problem can be treated separately. The first category of experiments aimed at explaining the capability of relatively large grains to form tightly-packed clusters or arrays, with implications for the evolution of domical vaults above the cavities. Using cubes, and alternatively also light beads with textured surfaces, we have found that three-component granular mixtures (e.g., varying around bulk amounts $\sim 1: 1: 1$, with stepwise differences in grain sizes of about $\times 1.66$ ) may have a considerably enhanced capability of forming self-assembling, grain-supported skeleton structures in the sediment. It was suggested that the abundance and characteristics of these grains in the relatively coarser fraction might be significant for stromatactis-forming sediments in general, and this can serve as a possible basis for further experimental work in this area. It is noteworthy that several other types of angular-grained materials, e.g., the standard two-component mixtures or those having too large a size-gap distribution, were of no relevance to stromatactis-cavity production.

The second class of experiments was based on combining a bidisperse mixture of relatively large angular grains with a polydisperse, broad unimodal matrix of small angular grains. However, the grain-size gap between these two components was medium, being roughly equal to the grain-size ranges of the components. It was proven that both the components were individually inactive in stromatactis-forming process. The results of these experiments were essential for demonstrating the great stromatactissupporting capacity of large grains, because when they were added they abruptly accelerated the formation of spacious stromatactis systems, even in these inactive materials. The highly positive effect of the added large grains was further confirmed by using artificial crinoid columnals. This demonstrated the relevance of another effect besides the alternative initiation of dynamic plugging, which is the presence of large pores among large grains that can increase the channelized flow of diluted fluids upwards (and eventually also downwards). This dynamically evolving system in the broad middle part of the sediment, confined from above and below, has a certain structural regularity, but also generates chaos. For example, the confined fluids can penetrate the walls of individual cavities, forming jets that 
are directed diagonally upward or with random distortions, and they can also completely move laterally or upwards from the original place. From these dynamic processes we can conclude that even modest amounts of crinoid columnals can significantly accelerate the formation of the rapidly formed, true stromatactis cavities. In addition, it seems that other related types of cavities can be supported by the presence of these disarticulated columnals (e.g., the cavities caused by arching and differential collapse of the granular sediments, or cavities related to the earliest forms of overpressurised, bedding-parallel cracks).

It is certainly difficult to assess all aspects of these complex processes at once. The principal aim of this study was, therefore, to introduce our simplified experiments, which can subsequently be used to determine these and many other aspects in more exact terms.

\section{Acknowledgements}

Financial support from the Grant Agency of Academy of Sciences of the Czech Republic is particularly acknowledged: Palaeoenvironments - KJB307020602, stratigraphy - KJB300130613, rock structures - IAA3013406, and technical aspects of this research - AV0Z30130516. The authors thank K. Žák, J. Otava, and A. Piechota for their contributions of field data, F. Boulvain, R. Aubrecht, and F. Neuweiler for their critical and inspiring formal reviews, and M.E. Tucker, J.R. Ebert, and O. Bábek for their informal suggestions and comments. Thanks are also due to R. Bunganič, I. Kašík, V. Sedláček, I. Konopáčová, and M. Fridrich for technical assistance with material preparation, high-speed video recording, and other aspects of this study.

\section{References}

ARAnSON, I.S. \& Tsimring, L.S. 2005. Patterns and collective behavior in granular media: theoretical concepts. http://mti.msd.anl.gov/resources/AransonTsimringReview/aranson_tsimring.pdf, dated 15 July 2005, 1-49.

Armstrong, A.K. \& MACKevetT, E.M. JR. 1982. Stratigraphy and diagenetic history of the lower part of the Triassic Chitistone Limestone, Alaska. U.S. Geological Survey Professional Paper 1212-A, 1-26.

Aubrecht, R., Szulc, J., Michalík, J., Schlögl, J. \& WAGREICH, M. 2002a. Middle Jurassic stromatactis mudmound in the Pieniny Klippen Belt (Western Carpathians). Facies 47, 113-126.

Aubrecht, R., Krobicki, M., Wierzbowski, A., Matyja, A. \& SCHLÖGL, J. 2002b. Jurassic stromatactis mud mounds in the Pieniny Klippen Belt (Western Carpathians) - petrography and stratigraphy, 1-16. In BUCUR, I.I. \& FILIPESCU, S. (eds) Research advances in calcareous algae and microbial carbonates. Proc. $4^{\text {th }}$ IFAA Reg. Meeting Cluj-Napoca. Cluj University Press.

AwAzU, A. 2000. Size segregation and convection of granular mixtures almost completely packed in a thin rotating box. Physical Review Letters 84(20), 4585-4588.
Barbieri, R., Ori, G.G. \& Cavalazzi, B. 2004. A Silurian cold-seep ecosystem from the Middle Atlas, Morocco. Palaios 19(6), 527-542.

BATCHELOR, G.K. \& RENSBURG, R.W.J. vAN 1986. Structure formation in bidisperse formation. Journal of Fluid Mechanics 166, 379-407.

BAtHURST, R.G.C. 1959. The cavernous structure of some Mississippian stromatactis reefs in Lancashire, England. Journal of Sedimentary Petrology 29, 365-376.

BATHURST, R.G.C. 1980. Stromatactis-origin related to submarine cemented crusts in Palaeozoic mud mounds. Geology 8, 131-134.

BAthURST, R.G.C. 1982. Genesis of stromatactis cavities between submarine crusts in Palaeozoic carbonate mud buildups. Journal of the Geological Society of London 139, 165-181.

Bernet-Rollande, M.C., Maurin, A.F. \& Monty, C.L.V. 1981. De la bactérie au réservoir carbonaté. Pétrole et Techniques (La revue de l'Association française des Techniciens et Professionnels du Pétrole) 283, 96-98.

BERRES, S. \& BÜRGER, R. 2003. On gravity and centrifugal settling of polydisperse suspensions forming compressible sediments. International Journal of Solids and Structures 40, 4965-4987.

Berres, S., BÜrger, R., KARLSEN, K.H. \& TORY, E.M. 2003. Strongly degenerate parabolic-hyperbolic systems modeling polydisperse sedimentation with compression. SIAM Journal on Applied Mathematics 64(1), 41-80.

Blanchette, F. \& Bush, J.W.M. 2005. Particle concentration evolution and sedimentation-induced instabilities in a stably stratified environment. Physics of Fluids 17, 073302, doi: 10.1063/1.1947987, Online, 1-11.

BosenCE, D.W.J. \& BRidges, P. 1995. Origin and evolution of carbonate mud-mounds, 3-9. In MonTy, C.L.V., Bosence, D.W.J., Bridges, P.H. \& PRATT, B.R. (eds) Carbonate mudmounds: their origin and evolution. International Association of Sedimentologist, Special Publications 23.

Boulvain, F. 1993. Sédimentologie et diagenese des monticules micritiques "F2j" du Frasnien de l'Ardenne. Service Géologique de Belgique, Papier Professionel 2(260), 1-427.

Boulvain, F. 2001. Facies architecture and diagenesis of Belgian Late Frasnian carbonate mounds. Sedimentary Geology 145, 269-294.

Boulvain, F., Cornet, P., Da Silva, A.-C., Delaite, G., Demany, B., Humblet, M., Renard, M. \& Coen-Aubert, M. 2004. Reconstructing atoll-like mounds from the Frasnian of Belgium. Facies 50(2), 313-326.

Bourque, P.A. \& Gignac, H. 1983. Sponge-constructed stromatactis mud mounds, Silurian of Gaspé, Québec. Journal of Sedimentary Petrology 53, 521-532.

Bourque, P.A., Neuweiler, F. \& Boulvain, F. 2004. The mud-mound system: products and processes. $32^{\text {nd }}$ Int. Geol. Congress, Florence, Italy. CD-ROM Abstracts 2, pp. 1079.

Bourrouilh, R., Bourque, P.-A., Dansereau, P., BourROUILH-LE, J.F.G. \& WeyANT, P. 1998. Synsedimentary tectonics, mud-mounds and sea-level changes on a Palaeozoic carbonate platform margin: a Devonian Montagne Noire example (France). Sedimentary Geology 118(1), 95-118.

Breu, A.P.J., EnSNer, H.M., Kruelle, C.A. \& RehberG, I. 2003. Reversing the Brazil-nut effect: competition between percolation and condensation. Physical Review Letters 90(1), 014302. 
CARdoso, S.S. \& Woods, A.W. 1995. On convection and mixing driven by sedimentation. Journal of Fluid Mechanics 285, 165-180.

Chlupáč, I., HavlíčeK, V., Kříž, J., Kukal, Z. \& Štorch, P. 1998. Palaeozoic of the Barrandian (Cambrian to Devonian). 183 pp. Publication of the Czech Geological Survey, Prague.

DA Silva, A.-C. \& Boulvain, F. 2004. From palaeosols to carbonate mounds: facies and environments of the middle Frasnian platform in Belgium. Geological Quarterly 48(3), 253-266.

DelecAt, S. \& ReitNer, J. 2005. Sponge communities from the Lower Liassic of Adnet (Northern Calcareous Alps, Austria). Facies 51, 385-404.

Desbordes, B. \& Maurin, A.F. 1974. Troix exemples d'études du Frasnien de l'Alberta, Canada. Notes et Mémoires de la Compagnie Française des Pétroles (Paris) 11, 293-336.

DiekEN, G. 1996. Karbonatmikrofazies, Paläoökologie und Genese der Stromatactis-Strukturen des Suchomasty- und des basalen Acanthopyge-Kalksteins im Barrandium (Tschechische Republik). Aachener Geowissenschaftliche Beiträge 19, 1-148.

DuPONT, E. 1881. Sur l'origine des calcaires dévoniens de la Belgique. Bulletin de l'Académie royale des Sciences, des Lettres et des Beaux-Arts de Belgique, $3^{\circ}$ série, 2(9-10), 264-280.

Duran, J., Kolb, E. \& VAnel, L. 1998. Static friction and arch formation in granular materials. Physical Review $E$ (The American Physical Society) 58(1), 805-812.

Dzubiella, J. \& Löwen, H. 2002. Pattern formation in driven colloidal mixtures: tilted driving forces and re-entrant crystal freezing. Journal of Physics Condensed Matter 14, 9383-9395.

FlAJS, G. \& HÜSSNER, H.M. 1993. A microbial model for the Lower Devonian stromatactis mud mounds of the Montagne Noire (France). Facies 29, 179-194.

Gargett, A., Wells, J., Tejada-Martínez, A.E. \& Grosch, C.E. 2004. Langmuir supercells: a mechanism for sediment resuspension and transport in shallow seas. Science 10(December 2004), 1925-1928.

Gnoli, M., JaAnuson, V., Leone, F. \& Serpagli, E. 1981. A Lower Devonian stromatactis-bearing carbonate mound from southern Sardinia. Neues Jahrbuch für Geologie und Paläontologie, Monatshefte 1981(6), 339-345.

Gray, T.E., AleXander, J. \& LeEDER, M.R. 2005. Quantifying velocity and turbulence structure in depositing sustained turbidity currents across breaks in slope. Sedimentology 52, 467-488.

GutTERidge, P. 2003. The reef at High Tor. Mercian Geologist 15(4), 235-237.

HECKEL, P.H. 1972. Possible inorganic origin for stromatactis in calcilutite mounds in the Tully Limestone, Devonian of New York. Journal of Sedimentary Petrology 42, 1-7.

Hilali, A., LachKem, H. \& Boulvain, F. 1999. Comparaison des Kess-kess de Hmar Lakhdad (Emsien, Maroc) et des monticules micritiques du Massif de Philippeville (Frasnien, Belgique). Geologica Belgica 1(1998), 17-31.

Hill, R., LEE, E.H. \& TuPPER, S.J. 1947. The theory of wedge indentation of ductile materials. Proceedings of the Royal Society of London, Series A, Mathematical and Physical Sciences 188(1013), 273-289.
HLADIL, J. 2005a. Stromatactis in glass of water: An experiment simulating formation of particular cavities in limestone sediments (in Czech). Vesmír 84(7), 388-394.

HLADIL, J. 2005b. The formation of stromatactis-type fenestral structures during the sedimentation of experimental slurries a possible clue to a 120 -year-old puzzle about stromatactis. Bulletin of Geosciences 80(3), 193-211.

Hoyal, D.C., Bursik, M.I. \& AtKinson, J.F. 1999. Settlingdriven convection: a mechanism of sedimentation from stratified fluids. Journal of Geophysical Research 104(C4), 7953-7966.

Huppert, H.E., KerR, R.C., Lister, J.R. \& TuRner, J.S. 1991. Convection and particle entrainment driven by differential sedimentation. Journal of Fluid Mechanics 226, 349-369.

JAMES, N.P. 1984. Reefs. Geoscience Canada Reprint Series 1, 229-244.

Kaufmann, B., Reinhold, C. \& Schauer, M. 1999. Concentric-zoned calcite cements of Middle Devonian carbonate mounds of the Mader Basin (eastern Anti-Atlas, Morocco) - a combined cathodoluminescence and microprobe study. Neues Jahrbuch für Geologie und Paläontologie, Abhandlungen $214,95-110$.

KaufmanN, B. \& WendT, J. 2000. Calcite cement successions in Middle Devonian (Givetian) carbonate mud buildups of the southern Ahnet Basin (Algerian Sahara). Carbonates Evaporites 15, 149-161.

KERR, R.C. 1991. Erosion of stable density gradient by sedimentation-driven convection. Nature 353, 423-425.

KERR, R.C. \& LISTER, J.R. 1992. Further results for convection driven by the differential sedimentation of particles. Journal of Fluid Mechanics 243, 227-245.

Krause, F.F., Scotese, C.R., Nieto, C., Sayegh, S.G., HopKINS, J.C. \& MEYER, R.O. 2004. Paleozoic stromatactis and zebra carbonate mud-mounds: global abundance and paleogeographic distribution. Geology 32, 181-184.

KUKAL, Z. 1971. Open-space structures in the Devonian limestones of the Barrandian (central Bohemia). Časopis pro mineralogii a geologii 16, 345-362.

LEES, A. \& Miller, J. 1985. Facies variation in Waulsortian buildups. Part 2. Mid-Dinantian buildups from Europe and North America. Geological Journal 20, 159-180.

LeEs, A. \& Miller, J. 1995. Waulsortian banks, 191-271. In Monty, C.L.V., Bosence, D.W.J., Bridges, P.H. \& Pratt, B.R. (eds) Carbonate mud-mounds: their origin and evolution. International Association of Sedimentologist, Special Publications 23.

Lowenstein, T.K., Demicco, R.V., TimofeEFF, M.N., HaRdie, L.A. \& BRENNAN, S.T. 2003. Ramifications of secular variations in seawater chemistry. Geological Society of America, 2003 Seattle Annual Meeting, Abstracts with Programs 35(6), 203.

Luding, S. \& HerRmanN, H.J. 1999. Cluster-growth in freely cooling granular media. Chaos 9, 673-681.

MackenZie, F.T. \& PigotT, J.D. 1981. Tectonic controls of Phanerozoic sedimentary rock cycling. Journal of the Geological Society of London 138, 183-196.

MAtYSZKIEwicZ, J. 1997. Stromatactis cavities and stromatactis-like cavities in the Upper Jurassic carbonate buildups at Mlynka and Zabierzów (Oxfordian, Southern Poland). Annales Societatis Geologorum Poloniae 67(1), 45-56. 
MAY, A. 2005. Die Stromatoporen des Devons und Silurs von Zentral-Böhmen (Tschechische Republik) und ihre Kommensalen. Zitteliana B25, 117-250.

MichalowsKi, R.L. \& PARK, N. 2004. Admissible stress fields and arching in piles of sand. Géotechnique (Institution of Civil Engineers, London) 54(8), 529-538.

MoNTY, C.L.V. 1995. The rise and nature of carbonate mudmounds: an introductory actualistic approach, 11-48. In MONTY, C.L.V., Bosence, D.W.J., Bridges, P.H. \& PratT, B.R. (eds) Carbonate mud mounds: their origin and evolution. International Association of Sedimentologists, Special Publication 23.

Monty, C.L.V., Bosence, D.W.J., BRIDGES, P.H. \& Pratt, B.R. (eds) 1995. Carbonate mud-mounds: their origin and evolution. 543 pp. International Association of Sedimentologists, Special Publication 23.

Mounj, D. \& Bourque, P.-A. 1998. The Devonian mound-like structures of the Maider Basin, Moroccan Sahara: mud mounds or pop-up structures? GACMAC-APGGQ Annual meeting, Québec, Abstracts with Program 23, ID220, A129.

NeUweILER, F. \& BeRnoulli, D. 2005. Mesozoic (Lower Jurassic) red stromatactis limestones from the Southern Alps (Arzo, Switzerland): calcite mineral authigenesis and syneresis-type deformation. International Journal of Earth Sciences 94, 130-146.

Neuweiler, F., Bourque, P.A. \& Boulvain, F. 2001. Why is stromatactis so rare in Mesozoic carbonate mud mounds? Terra Nova 13, 338-346.

Neuweiler, F., Gautret, P., Thiel, V., LANGe, R., Michaelis, W. \& ReITNER, J. 1999. Petrology of Lower Cretaceous carbonate mud mounds (Albian, N. Spain): insights into organomineralic deposits of the geological record. Sedimentology 46 , 837-859.

Peacock, D.C.P. 2003. A simple experiment to demonstrate overpressured fluids and soft sediment deformation. NAGT Journal of Geoscience Education 51(4), 410-414.

PRATT, B.R. 1982. Stromatolitic framework of carbonate mudmounds. Journal of Sedimentary Petrology 52, 1203-1227.

PRATT, B.R. 1998. Effects of synsedimentary earthquakes on cavity development in deep-water reefal mud-mounds. GACMAC-APGGQ Annual meeting, Québec, Abstracts with Program 23, ID554, A130.

Precali, R., Giani, M., Mariani, M., Grilli, F., Ferrari, C.R., PEČAR, O. \& PASCHINI, E. 2005. Mucilaginous aggregates in the northern Adriatic in the period 1999-2002: Typology and distribution. Science of the Total Environment 353, 10-23.

SANDBERG, P.A. 1983. An oscillating trend in Phanerozoic non-skeletal carbonate mineralogy. Nature 305, 19-22.

SCHMid, D.U., LeINFELDER, R.R. \& Nose, M. 2001. Growth dynamics and ecology of Upper Jurassic mounds, with comparisons to Mid-Palaeozoic mounds. Sedimentary Geology 145, 343-376.

SCHMid, D.U. \& Copper, P. 2004. Stromatactis fabric and dynamics revealed by computer-based $3 \mathrm{D}$ reconstruction. In Pena dos Reis, R., CAllapeZ, P. \& Dinis, P. (eds) $23^{\text {rd }} I A S$ Meeting of Sedimentology, Coimbra - September 15-17, 2004, Abstract Book. Coimbra, 248 pp.

Schnautz, T., Brito, R., Kruelle, C.A. \& RehberG, I. 2005. A horizontal Brazil-nut effect and its reverse. Physical Review Letters 95(2), 028001.
SHIRAKI, M. 1996. Upper Devonian sponge-algal mudmounds, southern flank of Miette reef complex, Jasper National Park, Alberta, Canada. Master's thesis, Department of Earth and Planetary Sciences, McGill University, Montreal (http://www. collectionscanada.ca/obj/s4/f2/dsk2/ftp04/mq29785.pdf), 104 pp.

Simo, J.A. \& Lehmann, P.J. 2000. Diagenetic history of Pipe Creek Jr. Reef, Silurian, north-central Indiana, U.S.A. Journal of Sedimentary Research 70(4), 937-951.

SivHed, U., ERLSTRÖM, M., BojeSEn-Koefoed, J.A. \& LÖFGREN, A. 2004. Upper Ordovician carbonate mounds on Gotland, central Baltic Sea: Distribution, composition and reservoir characteristics. Journal of Petroleum Geology 27(2), 115-140.

StAnLEy, S.M. \& HARDIE, L.A. 1998. Secular oscillations in the carbonate mineralogy of reef-building and sediment-producing organisms driven by tectonically forced shifts in seawater chemistry. Palaeogeography, Palaeoclimatology, Palaeoecology 144, 3-19.

STEINER, J. 1967. The sequence of geological events and the dynamics of the Milky Way Galaxy. Journal of the Geological Society of Australia 14(1), 99-131.

VELEBILOVÁ, L. \& ŠARF, P. 1996. Application of microfacies analysis in the Lower Devonian of the Barrandian, central Bohemia. Journal of the Czech Geological Society 41(1-2), 105-115.

WALLACE, M.W. 1987. The role of internal erosion and sedimentation in the formation of stromatactis mudstones associated lithologies. Journal of Sedimentary Petrology 57, 695-700.

WEBB, G.E. 1996. Was Phanerozoic reef history controlled by the distribution of non-enzymatically secreted reef carbonates (microbial carbonate and biological induced cement)? Sedimentology 43, 947-971.

WEILAND, R.H., FESSAS, Y.P. \& RAMARAO, B.V. 1984. On instabilities arising during sedimentation of two-component mixtures of solids. Journal of Fluid Mechanics 142, 383-389.

Wendt, J., Kaufmann, B. \& BelKa, Z. 2001. An exhumed Palaeozoic underwater scenery: the Visean mud mounds of the eastern Anti-Atlas (Morocco). Sedimentary Geology 145, 215-233.

Wet, C.B. De, Frey, H.M., Gaswirth, S.B., Mora, C.I., RAHNIS, M. \& BRUNO, C.R. 2004. Origin of meter-scale submarine cavities and herringbone calcite cement in a Cambrian microbial reef, Ledger Formation (U.S.A.). Journal of Sedimentary Research 74(6), 914-923.

Wilber, R.J. \& NEUMANN, A.C. 1993. Effects of submarine cementation on microfabrics and physical properties of carbonate slope deposits, northern Bahamas, 79-94. In REZAK, R. \& Lavoie, D.L. (eds) Carbonate microfabrics. Frontiers in Sedimentary Geology 6.

Williams, R.A., Amarasinghe, W.B.K., Simons, S.J.R. \& Xie, C.G. 1991. Sedimentation behaviour of complex polydisperse suspensions. Powder Technology 65(1-3), 411-432.

Woods, A.D. 2002. The role of subcutaneous fluid escape in the formation of a cavity system within a mid-Ordovician (Whiterockian) mud mound at Meiklejohn Peak, southwestern Nevada. http://gsa.confex.com/gsa/2002AM/finalprogram/abstract_40553.htm, 2002 GSA Denver Meeting Paper. 